\title{
ALCOHOL HYPOGLYCEMIA. I. CARBOHYDRATE METABOLISM OF PATIENTS WITH CLINICAL ALCOHOL HYPOGLYCEMIA AND THE EXPERIMENTAL REPRODUCTION OF THE SYNDROME WITH PURE ETHANOL*
}

\author{
By NORBERT FREINKEL, $\dagger$ DAVID L. SINGER, RONALD A. ARKY, SHELDON J. \\ BLEICHER, $\ddagger$ JOHN B. ANDERSON, AND CYNTHIA K. SILBERT \\ (From the Thorndike Memorial Laboratory and Second and Fourth [Harvard] Medical \\ Services, Boston City Hospital, and the Department of Medicine, Harvard \\ Medical School, Boston, Mass.)
}

(Submitted for publication January 16, 1963; accepted March 21, 1963)

In 1941, Brown and Harvey described hypoglycemia after alcoholic debauch in six chronic alcoholics from the Baltimore area (1). In 1942, Tucker and Porter noted four cases among chronic alcoholics from Richmond, Virginia (2). Since then, fewer than 100 instances of alcoholism associated with hypoglycemia have been reported, and most of these accounts have appeared in the foreign literature (3-12).

Certain summary statements about "alcohol hypoglycemia" are justified. First, although the condition was originally ascribed to "smoke," or more specifically, denatured alcohol solvents ("Solox") ${ }^{1}(1,2)$, later reports have excluded methanol, ethyl acetate, gasoline, or methyl isobutyl ketone $(3,4,7,9-12)$. Second, well-documented pediatric cases indicate that the addiction of the chronic alcoholic is not mandatory $(4,7,9$ -

* This work was supported in part by research grant A-1571 and training grant 2 A-5060 from the National Institute of Arthritis and Metabolic Diseases, U. S. Public Health Service. Presented in part at the fiftyfourth annual meeting of the American Society for Clinical Investigation, Atlantic City, N. J., April 30, 1962.

$\dagger$ Investigator, Howard Hughes Medical Institute.

$\ddagger$ Postdoctoral Research Fellow, U. S. Public Health Service.

1 The term "smoke" is derived from the cloudy appearance resulting from the addition of denatured alcohols to water. Analysis of four different samples of denatured alcohol solvent reported by Brown and Harvey disclosed the following average composition by volume: $86.5 \%$ ethyl alcohol; $4.4 \%$ methyl alcohol; $0.75 \%$ gasoline; and $3.5 \mathrm{~g}$ per $100 \mathrm{ml}$ ethyl acetate (1). "Solox" is the trade name for a shellac solvent prepared according to the formula: pure ethyl alcohol, 100 gal.; denatured grade wood alcohol, 5 gal.; gasoline, 1 gal.; ethyl acetate, undenatured, 1 gal.; methyl isobutyl ketone, 1 gal. (6). The absolute content of ethanol in all of these preparations is appreciable.
12). Third, although chronic malnutrition favors its occurrence, alcohol hypoglycemia has been reported in children on an adequate diet $(10,11)$. Fourth, blood ethanol concentrations, in the few instances measured $(3,4,7-11)$, have not exceeded the level of mild intoxication, about $200 \mathrm{mg}$ per $100 \mathrm{ml}$, so that transition from alcoholic stupor to hypoglycemic coma may be imperceptible. Finally, although normoglycemia may supervene without treatment, fatal terminations have been sufficiently frequent $(3,4,11,12)$ to highlight the necessity for recognition of the entity.

None of the clinical reports have resolved the following questions: Is there a unifying pattern of carbohydrate metabolism in patients with alcohol hypoglycemia? Is the hypoglycemia caused by ethanol per se, or is it due to congeners or to other impurities? With the consumption of ethanol so widespread, why is the entity so rare?

From September 1960 to June 1962, nine patients with hypoglycemia following alcoholic debauch were admitted to Boston City Hospital. ${ }^{2}$ Metabolic characterization of these patients and the response of some to pure alcohol under controlled conditions is the basis of this communication. Part of the material has already been presented in abstract form (13).

\section{SUBJECTS AND METHODS}

The patients were two female and six male chronic alcoholics, 32 to 81 years of age, and one 16-year-old schoolboy. Histories, endocrine evaluations, and initial tests of liver function are summarized in the Appendix.

\footnotetext{
2 The terms "alcohol" and "ethanol" are used interchangeably in subsequent portions of the text. In these nine patients, recent imbibition of any beverages other than standard commercial preparations of ethanol could not be proved.
} 
All patients were brought to the accident floor of Boston City Hospital in deep coma with varied neurological findings. Eight of the nine were admitted to the general medical wards of the hospital, whereas the ninth, H. W., was admitted directly to the metabolism ward of Thorndike Memorial Laboratory. Of the eight patients on the medical service, all except $H$. G. were subsequently transferred to the Thorndike metabolism ward.

On the Thorndike ward, all patients were maintained on constant diets of 2,300 to 2,600 calories containing 300 to $310 \mathrm{~g}$ of carbohydrate and 100 to $120 \mathrm{~g}$ of protein. Daily fluid intake consisted of $100 \mathrm{ml}$ per 100 calories in the diet. The patients were weighed daily and were permitted unrestricted activity on the ward throughout the period of observation.

Twenty-four hour urine specimens were collected in refrigerated containers. Blood specimens were obtained without stasis from indwelling venous or arterial needles and introduced into chilled tubes containing heparin. Plasma was separated by centrifugation at $4^{\circ} \mathrm{C}$ and stored at $-18^{\circ} \mathrm{C}$.

All measurements were obtained in duplicate or triplicate. Urinary glucose was quantitated by the method of Froesch and Renold (14). Urinary 17-ketosteroids (17$\mathrm{KS})$ and 17-ketogenic steroids (17-KGS) were determined by Bio-Science Laboratories ${ }^{3}$ by the methods of Sobel and associates (15) and Horwitt (16).

Plasma glucose (17), alcohol (18), phosphorus (19), amylase (20), and glutamic-oxalacetic transaminase, SGO-T (21), were estimated by standard techniques. Where marked hypoglycemia precluded satisfactory spectrophotometry by the Somogyi-Nelson method (17), protein-free filtrates of plasma were also analyzed for glucose enzymatically (22). The extraction procedure of Dole (23) was employed for the isolation of total plasma free fatty acids (FFA); heptane extracts were further purified by washing with aqueous $0.05 \% \quad \mathrm{H}_{2} \mathrm{SO}_{4}$ (24), and titration was performed with Nile Blue A as indicator. Electrolytes were estimated by standard flame photometry.

Immunoassay of plasma for insulin was performed by the method of Yalow and Berson (25).4 Samples of plasma, 50 or $100 \mu$, were combined with tracer quantities of $\mathrm{I}^{131}$-labeled porcine insulin, guinea pig antisera to porcine insulin, and sufficient Veronal buffer $(\mathrm{pH} 8.6$;

${ }^{3}$ Los Angeles, Calif.

${ }^{4}$ High specific activity preparations of $\mathrm{I}^{181}$-insulin were obtained from Abbott Laboratories, Oak Ridge, Tenn., which generously donated initial samples. Labeled material was purified by cellulose column (25), whenever the "intact" Ir1-insulin did not exceed $90 \%$ of the total radioactivity. For early assays, a crystalline preparation of Novo human insulin and guinea pig antiserum to porcine insulin were kindly furnished by Drs. S. A. Berson and R. Yalow. All later immunoassays were performed with antisera derived from guinea pigs that had been immunized to porcine insulin in this laboratory, and with human insulin and crystalline bovine and porcine insulins generously supplied by Drs. R. Kirtley and M. Root of Eli Lilly Co., Indianapolis, Ind. ionic strength, 0.05 ) containing $0.25 \%$ human serum albumin (Veronal albumin) to yield $0.5 \mathrm{ml}$. Duplicate 13point standard curves were prepared by adding unlabeled insulin to antibody and the labeled tracer. For assay of endogenous plasma insulin, the standard curves were constructed with human insulin; for assay of exogenous plasma insulin, as after iv administration of beef insulin, standard curves were prepared with crystalline insulin from the same species. Proportions of antibody and tracer were adjusted to yield an initial bound-tofree ratio of 1.0 to 2.5 .

Mixtures containing antibody were incubated for 4 days at $4^{\circ} \mathrm{C}$. Concurrently, control mixtures with antibody omitted (tracer plus Veronal albumin, and tracer plus Veronal albumin plus the human plasma that was being assayed) were also incubated. At the end of incubation, samples from each were applied to $1 \frac{1}{2}$-inch-wide strips of Whatman $3 \mathrm{MM}$ filter paper and resolved at room temperature by 25 to 35 minutes of hydrodynamic flow chromatography (26). The mobile plasma proteins were advanced about $10 \mathrm{~cm}$ beyond the site of application. The resultant resolution between "origin" radioactivity (unbound intact insulin) and "mobile" radioactivity (degradation products of the $\mathrm{I}^{131}$-insulin as well as antibody-bound tracer) did not differ from that obtained by slower chromatography at $4^{\circ} \mathrm{C}$. Strips were scanned in an automatically recording, thin-window flow counter to evaluate "trailing" and localize radioactive peaks. Subsequently, the strips were sectioned into two portions for radioactive assay in well-type scintillation counters. At least 1,000 counts above background were observed in each segment; for most analyses, the probable error of the radioactive measurement did not exceed $\pm 3 \%$. Estimates of the concentration of immunologically reactive insulin in plasma were derived from the standard curves after appropriate corrections for integrity of the tracer and the damaging potential of the plasma. In the absence of hemolysis, even 1:5 dilutions of plasma did not damage more than $5 \%$ of the labeled insulin.

Since plasma specimens frequently contained as much as $300 \mathrm{mg}$ per $100 \mathrm{ml}$ ethanol, experiments were instituted to assess whether alcohol enhanced the spontaneous degradation of the tracer $\mathrm{I}^{131}$-insulin, or altered the interaction between immunologically reactive insulin and antibody. The presence of 20 to $300 \mathrm{mg}$ per $100 \mathrm{ml}$ ethanol did not affect the integrity of the tracer during incubation of control mixtures. Moreover, when mixtures of tracer, Veronal albumin, and added human insulin (in quantities simulating physiological levels) were incubated for 4 days at $4^{\circ} \mathrm{C}$ with appropriate quantities of antibody, immunoassay yielded quantitative recovery of the added insulin:

$\begin{array}{ccc}\begin{array}{c}\text { Added } \\ \text { insulin } \\ m \mu g / m l\end{array} & \begin{array}{c}\text { Alcohol } \\ m g / 100 ~ m l\end{array} & \begin{array}{c}\text { Immunoassay } \\ \text { value } \\ m \mu g / m l\end{array} \\ .20 & 20 & .203 \\ .20 & 100 & .193 \\ .20 & 300 & .221 \\ .60 & 20 & .613 \\ .60 & 100 & .590 \\ .60 & 300 & .610\end{array}$


TABLE I

Oral glucose tolerance in patients with alcohol hypolgycemia

\begin{tabular}{|c|c|c|c|c|c|c|c|c|c|c|}
\hline \multirow[b]{2}{*}{ Patient } & \multirow{2}{*}{$\begin{array}{c}\text { Hospital } \\
\text { day }\end{array}$} & \multirow[b]{2}{*}{$w_{t}$} & \multicolumn{8}{|c|}{$\begin{array}{c}\text { Plasma glucose } \\
\text { Minutes after } 1.75 \mathrm{~g} \text { glucose per } \mathrm{kg} \text {, orally }\end{array}$} \\
\hline & & & $\mathbf{0}$ & 30 & 60 & 120 & 180 & 240 & 300 & 360 \\
\hline & & $k g$ & \multicolumn{8}{|c|}{$\mathrm{mg} / 100 \mathrm{ml}$} \\
\hline H.W. & 8 & 49.5 & 91 & 152 & 125 & 107 & 71 & 68 & 82 & 86 \\
\hline R.H. & 5 & 55.9 & 86 & & 113 & 111 & 85 & 69 & 77 & \\
\hline O.S. & 5 & 42.7 & 58 & 159 & 146 & 131 & 118 & & & \\
\hline E.J. & $\begin{array}{r}6 \\
24\end{array}$ & 52.7 & $\begin{array}{l}80 \\
76\end{array}$ & $\begin{array}{l}145 \\
112\end{array}$ & $\begin{array}{r}205 \\
81\end{array}$ & $\begin{array}{r}120 \\
63\end{array}$ & $\begin{array}{l}90 \\
45\end{array}$ & $\begin{array}{l}75 \\
42\end{array}$ & 60 & 65 \\
\hline W.R. & $\begin{array}{r}5 \\
26 \\
94\end{array}$ & $\begin{array}{l}54.5 \\
58.6 \\
58.2\end{array}$ & $\begin{array}{l}94 \\
76 \\
71\end{array}$ & $\begin{array}{l}158 \\
129 \\
112\end{array}$ & $\begin{array}{l}139 \\
156 \\
136\end{array}$ & $\begin{array}{l}136 \\
130 \\
109\end{array}$ & $\begin{array}{l}132 \\
123 \\
106\end{array}$ & $\begin{array}{r}128 \\
97 \\
60\end{array}$ & $\begin{array}{r}118 \\
88 \\
44\end{array}$ & $\begin{array}{r}111 \\
77 \\
77\end{array}$ \\
\hline H.G. & $\begin{array}{r}4 \\
29\end{array}$ & $\begin{array}{l}51.3 \\
55.7\end{array}$ & $\begin{array}{r}96 \\
110\end{array}$ & $\begin{array}{l}145 \\
186\end{array}$ & $\begin{array}{l}185 \\
194\end{array}$ & $\begin{array}{l}240 \\
260\end{array}$ & $\begin{array}{l}210 \\
172\end{array}$ & $\begin{array}{l}165 \\
140\end{array}$ & $\begin{array}{r}125 \\
46\end{array}$ & $\begin{array}{r}110 \\
79\end{array}$ \\
\hline W.Ry. & $\begin{array}{r}5 \\
46\end{array}$ & $\begin{array}{l}49.1 \\
53.6\end{array}$ & $\begin{array}{l}90 \\
78\end{array}$ & $\begin{array}{l}147 \\
124\end{array}$ & $\begin{array}{l}236 \\
183\end{array}$ & $\begin{array}{l}148 \\
193\end{array}$ & $\begin{array}{r}49 \\
172\end{array}$ & $\begin{array}{l}50 \\
43\end{array}$ & $\begin{array}{l}70 \\
57\end{array}$ & 67 \\
\hline J.B. & $\begin{array}{r}3 \\
57 \\
135\end{array}$ & $\begin{array}{l}39.5 \\
40.9 \\
46.3\end{array}$ & $\begin{array}{r}74 \\
86 \\
102\end{array}$ & $\begin{array}{l}152 \\
144 \\
162\end{array}$ & $\begin{array}{l}172 \\
181 \\
213\end{array}$ & $\begin{array}{l}250 \\
162 \\
227\end{array}$ & $\begin{array}{l}244 \\
111 \\
159\end{array}$ & $\begin{array}{r}250 \\
98 \\
106\end{array}$ & $\begin{array}{r}300 \\
97 \\
74\end{array}$ & $\begin{array}{l}80 \\
63\end{array}$ \\
\hline W.H. & $\begin{array}{r}8 \\
51 \\
94 \\
212 \\
336 \\
520\end{array}$ & $\begin{array}{l}46.6 \\
47.3 \\
53.0 \\
59.8 \\
62.9\end{array}$ & $\begin{array}{l}98 \\
71 \\
82 \\
83 \\
86 \\
74\end{array}$ & $\begin{array}{l}190 \\
115 \\
156 \\
133 \\
155 \\
159\end{array}$ & $\begin{array}{l}224 \\
163 \\
197 \\
153 \\
136 \\
201\end{array}$ & $\begin{array}{l}174 \\
143 \\
145 \\
132 \\
147\end{array}$ & $\begin{array}{r}240 \\
163 \\
106 \\
98 \\
121 \\
118\end{array}$ & $\begin{array}{r}125 \\
118 \\
82 \\
91 \\
107 \\
56\end{array}$ & $\begin{array}{l}80 \\
61 \\
67 \\
63 \\
66 \\
62\end{array}$ & $\begin{array}{l}63 \\
63 \\
63 \\
68 \\
71\end{array}$ \\
\hline
\end{tabular}

All acute tests of carbohydrate metabolism were initiated between 8:00 and 9:30 a.m. after food, but not water, had been withheld since 7:00 p.m. of the preceding evening.

Seventy-two hour fasts were usually begun after break- fast; patients were allowed water and unsweetened black coffee throughout. Blood samples were drawn at 12- to 24-hour intervals after patients had been recumbent for a minimum of 10 minutes.

For tests with alcohol, freshly opened bottles of ab-

TABLE II

Tolerance to iv insulin in patients with alcohol hypoglycemia

\begin{tabular}{|c|c|c|c|c|c|c|c|c|c|c|}
\hline \multirow[b]{2}{*}{ Patient } & \multirow[b]{2}{*}{ Day } & \multirow[b]{2}{*}{$\mathrm{Wt}$} & \multirow{2}{*}{$\begin{array}{l}\text { Initial } \\
\text { plasma } \\
\text { glucose }\end{array}$} & \multicolumn{7}{|c|}{$\begin{array}{l}\text { Plasma glucose, percentage of initial value } \\
\text { Minutes after } 0.1 \mathrm{U} \text { insulin per } \mathrm{kg} \text {, iv** }\end{array}$} \\
\hline & & & & 10 & 20 & 30 & 45 & 60 & 90 & 120 \\
\hline H.W. & 6 & $\begin{array}{c}\mathrm{kg} \\
49.1\end{array}$ & $\begin{array}{c}m g / 100 m l \\
94\end{array}$ & $\begin{array}{c}\% \\
83.0\end{array}$ & $\begin{array}{c}\% \\
54.2\end{array}$ & $\begin{array}{c}\% \\
39.4\end{array}$ & $\begin{array}{c}\% \\
41.5\end{array}$ & $\begin{array}{c}\% \\
42.5\end{array}$ & $\begin{array}{c}\% \\
75.5\end{array}$ & $\begin{array}{c}\% \\
79.8\end{array}$ \\
\hline R.H. & 3 & 55.0 & 87 & 80.4 & 56.3 & 32.2 & 69.0 & 79.3 & 102.3 & 100.0 \\
\hline O.S. & 27 & 44.5 & 56 & 73.2 & 66.1 & 60.7 & 50.0 & 51.8 & 76.8 & 76.8 \\
\hline W.R. & $\begin{array}{l}11 \\
98\end{array}$ & $\begin{array}{l}56.0 \\
57.3\end{array}$ & $\begin{array}{l}91 \\
90\end{array}$ & $\begin{array}{l}84.6 \\
71.1\end{array}$ & $\begin{array}{l}49.4 \\
44.4\end{array}$ & $\begin{array}{l}26.4 \\
28.8\end{array}$ & $\begin{array}{l}33.0 \\
31.1\end{array}$ & $\begin{array}{l}41.7 \\
33.3\end{array}$ & $\begin{array}{l}43.9 \\
35.5\end{array}$ & 60.4 \\
\hline H.G. & 37 & 56.8 & 91 & 81.3 & 58.2 & 51.6 & 38.5 & 31.9 & 45.0 & 61.5 \\
\hline W.Ry. & $\begin{array}{l}13 \\
34 \\
65\end{array}$ & $\begin{array}{l}51.7 \\
53.0 \\
55.5\end{array}$ & $\begin{array}{l}75 \\
61 \\
84\end{array}$ & $\begin{array}{l}83.6 \\
83.3\end{array}$ & $\begin{array}{l}44.0 \\
57.4 \\
44.0\end{array}$ & $\begin{array}{l}29.3 \\
45.9 \\
29.8\end{array}$ & $\begin{array}{l}55.7 \\
39.3\end{array}$ & $\begin{array}{l}40.0 \\
54.1 \\
40.5\end{array}$ & $\begin{array}{l}62.7 \\
67.2 \\
55.9\end{array}$ & $\begin{array}{l}85.3 \\
77.0 \\
61.9\end{array}$ \\
\hline J.B. & $\begin{array}{r}15 \\
58 \\
138\end{array}$ & $\begin{array}{l}40.0 \\
40.4 \\
46.4\end{array}$ & $\begin{array}{r}87 \\
92 \\
108\end{array}$ & & $\begin{array}{l}60.9 \\
64.1 \\
67.6\end{array}$ & $\begin{array}{l}43.7 \\
38.0 \\
46.3\end{array}$ & $\begin{array}{l}21.7 \\
35.2\end{array}$ & $\begin{array}{l}23.0 \\
29.3 \\
45.4\end{array}$ & $\begin{array}{l}33.3 \\
42.4 \\
59.2\end{array}$ & $\begin{array}{l}46.0 \\
57.6 \\
68.5\end{array}$ \\
\hline W.H. & $\begin{array}{r}30 \\
102 \\
202 \\
333 \\
518\end{array}$ & $\begin{array}{l}48.4 \\
51.8 \\
59.5 \\
62.9\end{array}$ & $\begin{array}{r}100 \\
76 \\
71 \\
93 \\
81\end{array}$ & $\begin{array}{l}91.0 \\
77.6 \\
77.4 \\
85.2\end{array}$ & $\begin{array}{l}59.0 \\
53.9 \\
73.2 \\
48.4 \\
60.5\end{array}$ & $\begin{array}{l}44.0 \\
43.4 \\
45.1 \\
25.8 \\
39.5\end{array}$ & $\begin{array}{l}32.0 \\
43.4 \\
36.6 \\
32.2 \\
32.1\end{array}$ & $\begin{array}{l}32.0 \\
55.3 \\
39.4 \\
46.2 \\
40.7\end{array}$ & $\begin{array}{l}59.0 \\
76.3 \\
63.4 \\
75.3 \\
65.4\end{array}$ & $\begin{array}{l}71.0 \\
89.5 \\
67.6 \\
71.4\end{array}$ \\
\hline
\end{tabular}

* Insulin was administered intravenously after being diluted with isotonic saline to prepare injection mixtures containing $1.0 \mathrm{U}$ insulin per $\mathrm{ml}$. 
TABLE III

Response to iv glucagon in patients with alcohol hypoglycemia

\begin{tabular}{|c|c|c|c|c|c|c|c|c|}
\hline \multirow[b]{2}{*}{ Patient } & \multirow[b]{2}{*}{ Day } & \multirow[b]{2}{*}{ Wt } & \multicolumn{6}{|c|}{$\begin{array}{l}\text { Plasma glucose } \\
\text { Minutes ater } 1.0 \mathrm{mg} \text { glucagon, iv* }\end{array}$} \\
\hline & & & 0 & 15 & 30 & 60 & 90 & 120 \\
\hline & & $\mathrm{kg}$ & \multicolumn{6}{|c|}{$m g / 100 \mathrm{ml}$} \\
\hline o.s. & 34 & 46.8 & 57 & 88 & 91 & 71 & 59 & 59 \\
\hline W.R. & 19 & 54.4 & 82 & 112 & 125 & 114 & 102 & 99 \\
\hline W.Ry. & 3 & & 62 & & 98 & 72 & 61 & 59 \\
\hline J.B. & $\begin{array}{l}20 \\
56\end{array}$ & $\begin{array}{l}42.3 \\
40.9\end{array}$ & $\begin{array}{l}75 \\
78\end{array}$ & $\begin{array}{r}87 \\
106\end{array}$ & $\begin{array}{r}98 \\
112\end{array}$ & $\begin{array}{l}90 \\
91\end{array}$ & $\begin{array}{l}78 \\
77\end{array}$ & $\begin{array}{l}73 \\
65\end{array}$ \\
\hline W.H. & 93 & 47.3 & 77 & 111 & 120 & 112 & 91 & 83 \\
\hline
\end{tabular}

* Glucagon was administered intravenously after being solubilized with commercial diluent to prepare injection mixtures containing 1.0 mg glucagon per $\mathrm{ml}$.

solute alcohol ${ }^{5}$ were appropriately diluted with isotonic saline. Metopirone ${ }^{6}$ (2-methyl-1,2-di-3-pyridyl-1-propanone) tests were performed as recommended by Liddle (27).

\section{RESULTS AND COMMENTS}

\section{Basal carbohydrate metabolism}

After adequate alimentation had been established, standard tests of carbohydrate metabolism

${ }^{5}$ U.S.P., Reagent Quality, U. S. Industrial Chemicals Co., distributed by Fisher Scientific Corporation, New York, N. Y.

6 Generously provided by Dr. C. H. Sullivan of Ciba Pharmaceutical Products, Inc., Summit, N. J. were performed in the nine patients to delineate a metabolic "profile" characteristic of the group. In those patients amenable to prolonged hospitalization, the tests were repeated at intervals to document the progression of metabolic patterns.

Disposition of exogenous glucose. Values for blood sugar after overnight fast were invariably within normal limits (Tables I to IV). Capacities for the disposition of exogenous glucose were challenged by giving $1.75 \mathrm{~g}$ glucose per $\mathrm{kg}$ by mouth after 13 to 14 hours of fasting. ${ }^{7}$ Results are summarized in Table I. Initial examinations were performed on hospital days 3 to 8 , after a minimum of 2 days on a diet containing more than $250 \mathrm{~g}$ of carbohydrate. Oral glucose tolerance was normal in two patients, H. W. and R. H., mildly abnormal in three, O. S., E. J., and W. R., and

7 None of the patients exhibited steatorrhea, and in the four patients in whom it was examined, the absorption of xylose was within normal limits. Accordingly, oral administration of glucose was chosen in preference to iv. The former more closely approximates the characteristics of normal alimentation, whereas the latter, by the primary introduction of glucose into the systemic circulation and the precipitous elevation of blood sugar, constitutes a form of glycemic challenge without physiological parallel, except perhaps during glycogenolysis.

TABLE IV

Response to iv tolbutamide in patients with alcohol hypoglycemia

\begin{tabular}{|c|c|c|c|c|c|c|c|c|c|}
\hline \multirow[b]{2}{*}{ Patient } & \multirow[b]{2}{*}{ Day } & \multirow[b]{2}{*}{ Wt } & \multirow{2}{*}{$\begin{array}{l}\text { Initial } \\
\text { plasma } \\
\text { glucose }\end{array}$} & \multicolumn{6}{|c|}{$\begin{array}{l}\text { Plasma glucose, percentage of initial value } \\
\text { Minutes after } 1.0 \mathrm{~g} \text { tolbutamide, iv* }\end{array}$} \\
\hline & & & & 30 & 60 & 90 & 120 & 150 & 180 \\
\hline H.W. & 5 & $\begin{array}{l}\mathrm{kg} \\
49.1\end{array}$ & $\begin{array}{c}m g / 100 m l \\
86\end{array}$ & $\begin{array}{c}\% \\
53.5\end{array}$ & $\begin{array}{c}\% \\
46.5\end{array}$ & $\begin{array}{c}\% \\
67.4\end{array}$ & $\begin{array}{c}\% \\
76.8\end{array}$ & $\begin{array}{c}\% \\
80.2\end{array}$ & $\begin{array}{c}\% \\
81.4\end{array}$ \\
\hline R.H. & $\begin{array}{r}2 \\
16\end{array}$ & $\begin{array}{l}54.5 \\
56.3\end{array}$ & $\begin{array}{l}91 \\
81\end{array}$ & $\begin{array}{l}72.5 \\
65.4\end{array}$ & $\begin{array}{l}54.9 \\
76.5\end{array}$ & $\begin{array}{l}53.8 \\
86.4\end{array}$ & $\begin{array}{l}56.0 \\
97.5\end{array}$ & $\begin{array}{l}52.7 \\
93.8\end{array}$ & $\begin{array}{l}72.5 \\
90.1\end{array}$ \\
\hline O.S. & 25 & 44.1 & 64 & 89.0 & 80.0 & 81.2 & 92.2 & & 92.2 \\
\hline E.J. & $\begin{array}{l}17 \\
37\end{array}$ & $\begin{array}{l}52.3 \\
56.2\end{array}$ & $\begin{array}{l}60 \\
84\end{array}$ & $\begin{array}{l}80.0 \\
63.1\end{array}$ & $\begin{array}{l}81.7 \\
58.3\end{array}$ & $\begin{array}{l}66.7 \\
82.1\end{array}$ & 73.3 & $\begin{array}{l}76.7 \\
83.3\end{array}$ & $\begin{array}{l}80.0 \\
90.5\end{array}$ \\
\hline W.R. & $\begin{array}{r}4 \\
97\end{array}$ & $\begin{array}{l}54.3 \\
57.7\end{array}$ & $\begin{array}{l}96 \\
91\end{array}$ & $\begin{array}{l}62.5 \\
35.2\end{array}$ & $\begin{array}{l}55.2 \\
61.5\end{array}$ & $\begin{array}{l}74.0 \\
76.9\end{array}$ & $\begin{array}{l}77.1 \\
74.7\end{array}$ & $\begin{array}{l}84.4 \\
79.1\end{array}$ & $\begin{array}{l}84.4 \\
76.9\end{array}$ \\
\hline H.G. & 20 & 54.3 & 124 & 85.5 & 83.1 & 76.6 & 73.4 & 68.5 & 73.4 \\
\hline W.Ry. & $\begin{array}{l}10 \\
51 \\
62\end{array}$ & $\begin{array}{l}51.3 \\
54.6 \\
55.5\end{array}$ & $\begin{array}{l}73 \\
86 \\
87\end{array}$ & $\begin{array}{l}67.1 \\
66.3 \\
73.6\end{array}$ & $\begin{array}{l}54.8 \\
53.5 \\
59.8\end{array}$ & $\begin{array}{l}63.0 \\
63.9 \\
66.7\end{array}$ & $\begin{array}{l}60.3 \\
68.6 \\
58.6\end{array}$ & $\begin{array}{l}65.1 \\
68.9\end{array}$ & $\begin{array}{l}57.5 \\
62.8 \\
68.9\end{array}$ \\
\hline J.B. & $\begin{array}{r}12 \\
54 \\
136\end{array}$ & $\begin{array}{l}40.0 \\
41.3 \\
46.3\end{array}$ & $\begin{array}{r}65 \\
104 \\
106\end{array}$ & $\begin{array}{l}66.1 \\
88.5 \\
80.2\end{array}$ & $\begin{array}{l}46.1 \\
40.4 \\
70.7\end{array}$ & $\begin{array}{l}44.6 \\
43.3 \\
66.0\end{array}$ & $\begin{array}{l}51.9 \\
66.0\end{array}$ & 61.5 & $\begin{array}{l}59.6 \\
70.7\end{array}$ \\
\hline W.H. & $\begin{array}{r}77 \\
328 \\
522\end{array}$ & $\begin{array}{l}47.3 \\
59.1 \\
62.9\end{array}$ & $\begin{array}{l}71 \\
90 \\
81\end{array}$ & $\begin{array}{l}71.8 \\
64.4 \\
61.7\end{array}$ & $\begin{array}{l}67.6 \\
60.0 \\
64.2\end{array}$ & $\begin{array}{l}81.7 \\
71.1 \\
72.8\end{array}$ & $\begin{array}{l}90.1 \\
84.4 \\
79.0\end{array}$ & $\begin{array}{l}92.9 \\
84.4 \\
86.4\end{array}$ & $\begin{array}{l}98.6 \\
85.5 \\
87.6\end{array}$ \\
\hline
\end{tabular}

* Tolbutamide was administered intravenously after being solubilized with isotonic saline or commercial diluent to prepare injection mixtures containing 0.1 tolbutamide per $\mathrm{ml}$. 
frankly diabetic in the remaining four subjects, H. G., W. Ry., J. B., and W. H.

Repeat observations were possible in six patients; all had gained weight in the interval (Tables I to IV). For W. R. and E. J., oral glucose tolerance became normal, but in the other four subjects, glucose disposition remained retarded despite some improvement (Table I). In four of these six patients, the relative improvement in glucose tolerance was accompanied by an "overshoot" phenomenon, i.e., plasma glucose declined to levels below $50 \mathrm{mg}$ per $100 \mathrm{ml}$ within 3 to 5 hours after oral glucose. None exhibited clinical glycosuria during hospitalization. Enzymatic estimates of 24-hour urinary glucose did not exceed $600 \mathrm{mg}$ even in the patients with persistently abnormal tests of oral glucose tolerance.

Preservation of endogenous glucose. Sustained normoglycemia in the absence of exogenous nutrients is effected by a balanced interaction between the production and the utilization of endogenous glucose. To assess the functional reserve maintaining this equilibrium, challenges were instituted with insulin, tolbutamide, and prolonged starvation.

1) Tolerance to intravenous insulin. Intravenous injections of $0.1 \mathrm{U}$ per $\mathrm{kg}$ of "glucagon-free" insulin were given to eight of the nine patients after overnight fast. ${ }^{8}$ In normal subjects and in well-nourished hospital patients, this amount of insulin reduces blood sugar to about $50 \%$ of pretest values within 20 to 30 minutes (28-30), and it is offset by counterregulatory mechanisms that restore normal blood sugar within 90 to $120 \mathrm{~min}$ utes after insulin administration $(28,30)$. In our patients, during initial tests of insulin tolerance, on hospital days 6 to 37, nadir levels occurred at 30 to 60 minutes and averaged $33.0 \pm 2.96 \%{ }^{\circ}$ of the pretest values (Table II). All except the 16-yearold schoolboy, R. H., displayed some degree of hypoglycemic unresponsiveness, so that restoration

8 For tests of insulin tolerance, two preparations of "glucagon-free" insulin were employed: trypsin-treated crystalline porcine insulin (Eli Lilly lot no. 499667), which was dissolved in appropriate diluting solutions in. this laboratory, and trypsin-treated bovine insulin (Eli Lilly lot no. W3606), which was already solubilized upon receipt in this laboratory. Accurate delivery of test doses was facilitated by diluting the insulin to $1.0 \mathrm{U}$ per $\mathrm{ml}$ with isotonic saline before administration.

${ }^{9}$ Mean $\pm \mathrm{SE}$ of the mean.

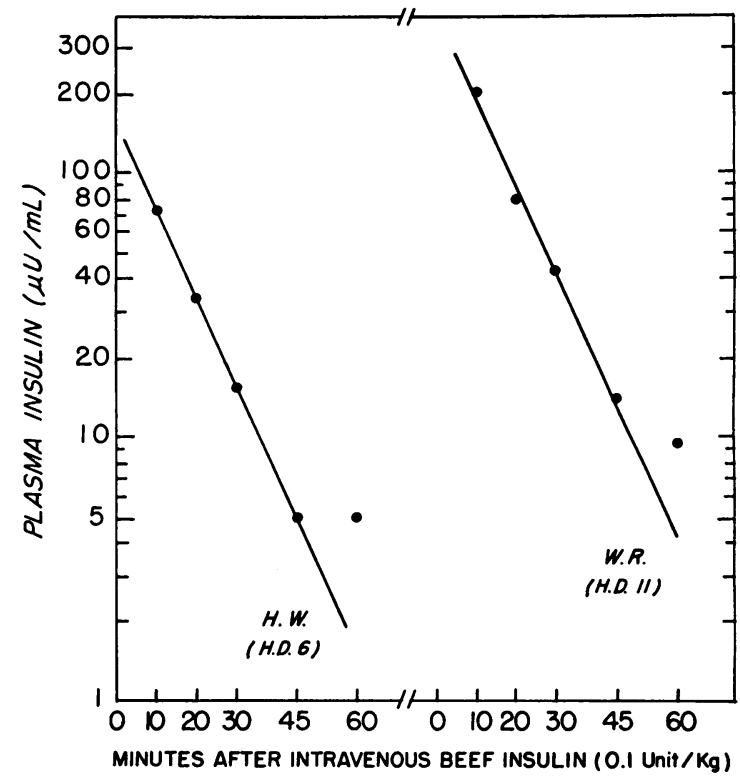

Fig. 1. Clearance of EXOGENOUS INSUlin From CIRCULATION OF PATIENTS WITH CLINICAL ALCOHOL HYPOGLYCEMIA. After iv administration of $0.1 \mathrm{U}$ per $\mathrm{kg}$ crystalline beef insulin, plasma specimens were obtained without stasis at timed intervals. Immunoassay values for insulin are shown. (Concurrent values for plasma glucose are presented in Table II.) In all figures, the individual patients are designated by appropriate initials. Numerical values prefixed by $H$. D. denote the hospital day of the test of carbohydrate metabolism.

to the initial concentration of plasma glucose was not achieved within 120 minutes.

In the four patients in whom tests were repeated, the patterns persisted despite adequate diet and gain in weight (Table II). That gross inadequacies of stored glycogen were not implicated was documented by administering glucagon after overnight fasts to five of the patients (Table III). Intravenous injection of $1 \mathrm{mg}$ glucagon on day 20 raised plasma glucose more than $30 \mathrm{mg}$ per $100 \mathrm{ml}$, in all except J. B. Even in J. B., improved response to glucagon (day 56 , Table III) was not accompanied by appreciable alteration in insulin tolerance on day 58 (Table II).

Plasma specimens obtained during the challenge with insulin in J. B. on day $138, \mathrm{H}$. W. on day 6 , and W. R. on day 11 were analyzed by immunoassay to evaluate the possibility that the hypoglycemic unresponsiveness might result from abnormal intravascular persistence of hormone. No evidence for such delayed clearance was found. Exogenous insulin in venous plasma declined to 
levels below $10 \mu \mathrm{U}$ per $\mathrm{ml}$ within 45 minutes after injection. In H. W. and W. R., sufficient samples were examined to permit derivation of rate constants; half-times for the disappearance of the beef insulin from plasma during the first 45 minutes were 9.2 and 9.0 minutes, respectively (Figure 1 ).

In most subjects, the hypoglycemic response to insulin was accompanied by tachycardia and elevation of blood pressure. Such manifestations of autonomic discharge did not occur in J. B. and W. H., even with sufficient intervals between serial insulin administrations (Table II) to exclude the likelihood of adaptation phenomena (31). That this lack of autonomic reactivity was not due to impaired responsiveness of target tissues was documented with exogenous epinephrine. Intramuscular injection of $0.01 \mathrm{ml}$ per $\mathrm{kg}$ of $1: 1,000$ epinephrine (32) to J. B. on day 143 raised plasma glucose from fasting levels of 87 $\mathrm{mg}$ per $100 \mathrm{ml}$ to $94,112,128,119$, and $110 \mathrm{mg}$ per $100 \mathrm{ml}$ in $15,30,60,90$, and 120 minutes, respectively, while plasma FFA increased from $338 \mu$ moles per $\mathrm{L}$ to $620,967,1,174,560$, and $342 \mu$ moles per L. In W. H., on day 525, epinephrine increased plasma glucose from fasting levels of $78 \mathrm{mg}$ per $100 \mathrm{ml}$ to $95,126,143,132$, and $107 \mathrm{mg}$ per $100 \mathrm{ml}$, while plasma FFA rose from $476 \mu$ moles per $\mathrm{L}$ to $833,1,107,1,277,1,164$, and $683 \mu$ moles per L. Both subjects displayed appropriate pressor and tachycardiac responses to the exogenous epinephrine. Thus, their grossly deficient autonomic reaction to insulin hypoglycemia may be attributed to an inadequate mobilization of endogenous adrenergic counterregulators even without quantitative assays for catecholamines.

2) Response to intravenous tolbutamide. The pattern of blood-sugar response to the iv administration of $1.0 \mathrm{~g}$ sodium tolbutamide has been extensively documented (33-35). In nondiabetic subjects, an average maximal decline to 50 to $60 \%$ of pretest values is achieved in about $30 \mathrm{~min}-$ utes, and restoration to blood sugar levels greater than $80 \%$ of pretest values occurs within 90 minutes. In mild diabetics, the reduction is slower, so that the blood-sugar concentration at $30 \mathrm{~min}$ utes exceeds $73 \%$ of the initial values, and maximal reductions may be delayed for more than an hour. On the assumption that the response to tolbutamide is conditioned not only by the rate and quantity of insulin release and its extrapancreatic persistence, but also by the degree of induced hypoglycemia and the adequacy of counterregulating mechanisms, patients were challenged with tolbutamide after overnight fast (Table IV).

In their initial tolbutamide tests, O. S., E. J., and $\mathrm{H}$. G. displayed minimal reductions in blood sugar during the first 30 minutes. The remaining six patients exhibited 30-minute decrements that were compatible with normal rates of insulin release. Plasma glucose continued to decline in all nine patients, so that maximal reductions did not occur until 60 or more minutes after tolbutamide administration. Such delayed nadirs might have been anticipated in the three patients with the diabetic type of 30-minute response (33). In the others, the proloriged reductions were contrary to the usual experience in normal nondiabetic subjects $(33,35)$. In R. H., W. Ry., and J. B., the tolbutamide-induced hypoglycemia was prolonged to an extent that is classically associated with massive hepatoparenchymal disease or islet-cell tumors (35).

The complex interrelationships in tolbutamide action preclude definitive interpretation. Since adequate alimentation had been established, it is doubtful that inanition was contributory. Moreover, in two young adult, control subjects, we have not observed abnormal prolongation of tolbutamide-hypoglycemia even after 3 days of fasting. In $\mathrm{R}$. H., the initial tolbutamide test could have reflected an anomalous responsiveness of "alcoholprimed islet" tissue. In all of the others, the relative hypoglycemic unresponsiveness to standardized amounts of exogenous insulin (Table II) suggests that deficient counter regulation could result in an exaggerated response even to a normal release of endogenous insulin.

Examinations were repeated in six patients (Table IV). Reversions to more normal patterns were observed in four. In W. Ry. and J. B., the enhanced hypoglycemic potential of tolbutamide persisted. In J. B., this was now associated with a diabetic type of 30-minute response.

To correlate tolbutamide with a less well-defined potential iselt-cell secretogogue, L-leucine (36-38) was administered to $\mathrm{W}$. Ry. on day 60 and to W. H. on day 61 . Oral doses of $150 \mathrm{mg}$ per $\mathrm{kg}$ L-leucine did not appreciably reduce blood sugar in either subject. Respective values for plasma 
TABLE V

Tolerance to fasting in patients with alcohol hypoglycemia

\begin{tabular}{|c|c|c|c|c|c|c|c|c|c|c|}
\hline \multirow[b]{2}{*}{ Patient } & \multirow[b]{2}{*}{ Days } & \multicolumn{2}{|c|}{ Wt } & \multicolumn{6}{|c|}{$\begin{array}{l}\text { Plasma glucose } \\
\text { Hours of fasting }\end{array}$} & \multirow[b]{2}{*}{ Exercise* } \\
\hline & & Initial & Final & 12 & 24 & 36 & 48 & 60 & 72 & \\
\hline & & $\mathrm{kg}$ & $k g$ & \multicolumn{6}{|c|}{$m g / 100 m l$} & \\
\hline R.H. & $68-71 \dagger$ & 55.2 & 53.2 & 84 & 81 & 64 & 48 & 50 & 49 & \\
\hline O.S. & $35-37$ & 47.0 & 44.1 & 66 & 56 & 46 & 44 & 34 & & \\
\hline E.J. & $27-30$ & 52.7 & 51.4 & 81 & & 77 & 71 & & 60 & 69 \\
\hline W.R. & $12-15$ & 56.3 & 54.5 & 83 & 75 & 44 & 43 & 41 & 40 & 58 \\
\hline W.Ry. & $\begin{array}{l}37-40 \\
65-68\end{array}$ & $\begin{array}{l}53.4 \\
55.4\end{array}$ & $\begin{array}{l}52.0 \\
53.4\end{array}$ & 85 & $\begin{array}{l}69 \\
61\end{array}$ & 58 & $\begin{array}{l}38 \\
46\end{array}$ & 44 & $\begin{array}{l}42 \\
46\end{array}$ & 50 \\
\hline J.B. & $21-24$ & 42.3 & 39.3 & & 86 & 55 & 54 & & 53 & \\
\hline W.H. & $\begin{array}{l}102-105 \\
175-178 \\
242-245 \\
345-348 \\
549-552 \\
601-604 \ddagger \\
653-656\end{array}$ & $\begin{array}{l}48.4 \\
52.3 \\
55.5 \\
59.8 \\
62.7 \\
63.9 \\
65.3\end{array}$ & $\begin{array}{l}46.1 \\
49.5 \\
52.5 \\
56.6 \\
60.1 \\
62.0 \\
61.0\end{array}$ & $\begin{array}{l}78 \\
78 \\
81 \\
86 \\
80\end{array}$ & $\begin{array}{l}54 \\
67 \\
77 \\
78 \\
76 \\
80 \\
72\end{array}$ & $\begin{array}{l}52 \\
54 \\
65 \\
75 \\
61 \\
81 \\
58\end{array}$ & $\begin{array}{l}52 \\
53 \\
49 \\
\\
59 \\
67 \\
60\end{array}$ & $\begin{array}{l}49 \\
52 \\
50 \\
58 \\
69 \\
53\end{array}$ & $\begin{array}{l}50 \\
47 \\
52 \\
60 \\
51 \\
77 \\
59\end{array}$ & \\
\hline
\end{tabular}

* Exercise for 1 hour on a stationary bicycle was begun at the end of the 72-hour fast. Blood was drawn immediately after the end of the exercise.

$\dagger$ Fasting tolerance was assessed 68 to 71 days following the episode of clinical alcohol hypoglycemia. Patient was initially hospitalized for 27 days and readmitted to Thorndike metabolism ward 1 month later for additional studies including the 3-day fast.

$\ddagger$ Oral cortisone, $75 \mathrm{mg}$ every 8 hours, was administered throughout the period of fasting on days 601 to 604 .

glucose before and $30,60,90,120,150$, and 180 minutes after the administration of L-leucine were $83,80,77,76,76,75$, and $73 \mathrm{mg}$ per $100 \mathrm{ml}$ in W. Ry. and $81,86,85,77,83,73$, and $77 \mathrm{mg}$ per $100 \mathrm{ml}$ in W. $\mathrm{H}$.

3) Tolerance to fasting. Seven of the patients were subjected to 3-day fasts (Table V). In all except E. J., venous plasma glucose declined to levels below $60 \mathrm{mg}$ per $100 \mathrm{ml}$ after 48 hours of fasting and to values below $55 \mathrm{mg}$ per $100 \mathrm{ml}$ by 60 to 72 hours. In W. R., W. Ry., J. B., and on three occasions in W. H., plasma specimens were obtained near the end of the fast and analyzed for insulin by immunoassay. Insulin levels were not in excess of $11 \mu \mathrm{U}$ per ml.

Three patients were exercised at the end of the 3-day fast. One hour of pedaling a stationary bicycle did not effect further reductions of blood sugar (Table V). Rather, there was a variable but definite elevation of plasma glucose, suggesting that some mobilizable hepatic glycogen had been preserved.

In W. H., the administration of $75 \mathrm{mg}$ of oral cortisone every 8 hours (39) during one of his fasts attenuated his usual fall in blood sugar.

The decline in plasma glucose during 3 days of fasting in patients with alcohol hypoglycemia exceeded our findings in an age-matched control population from Boston City Hospital. In nine of ten control' subjects, venous plasma glucose was maintained at levels of $60 \mathrm{mg}$ per $100 \mathrm{ml}$ or greater during 72 hours of fasting.

Correlations between plasma glucose and FFA. In four patients, the correlative changes in plasma FFA were measured during tests of carbohydrate metabolism (Figure 2). During oral glucose tolerance, the delayed disposition of glucose loads was attended by prolonged reductions of FFA, and secondary "rebounds" of FFA (40) were minimal even during 6 hours of observations. Similarly, during exhibition of exogenous insulin, as well as during tolbutamide-induced mobilization of endogenous insulin, the abnormal hypoglycemic unresponsiveness was associated with an equal unresponsiveness of FFA. A counterregulatory upsurge of FFA was not observed until the absolute decrement in plasma glucose had been arrested. The results afford further evidence of a diminution in the mechanisms for counterregulation.

Possible role for alcohol. In some of the patients, amelioration of initially abnormal tests oc- 
curred during prolonged hospitalization. To assess the possibility that alcohol, per se, may have been contributory, $100 \mathrm{ml}(79 \mathrm{~g})$ of absolute ethanol was substituted for isocaloric quantities of fat in the constant diet of W. H. on days 115 to 180 (Figure 3). Although he continued to gain weight, alterations in oral glucose tolerance occurred, and his hypoglycemic unresponsiveness to exogenous insulin was exacerbated, although weekly tests of hepatic function [SGO-T, bromosulfophthalein (BSP), cephalin flocculation, etc.] did not change significantly, and repeat liver biopsy on day 157 disclosed normal liver without any fat globules.

\section{Effects of alcohol}

Since the clinical diagnosis of alcohol hypoglycemia was usually made retrospectively, the authors did not see most of the patients until the initial coma had been terminated by the administration of glucose. In the case of the 32-year-old white female $\mathrm{H}$. W., however, the authors were summoned in time to obtain adequate blood samples. H. W. was in deep coma with no localizing neurological signs nor other physical abnormalities. Rectal temperature was $94^{\circ} \mathrm{F}$, blood pressure was $120 / 90$, pulse was 60 beats per minute, and respiration was 10 breaths per minute. Venous plasma glucose was $6 \mathrm{mg}$ per $100 \mathrm{ml}$ with a plasma alcohol level of $149 \mathrm{mg}$ per $100 \mathrm{ml}$, SGO-T of $54 \mathrm{U}$, and amylase of 112 . Intravenous administration of $35 \mathrm{ml}$ of $50 \%$ glucose restored consciousness immediately and raised rectal temperature to $96.3^{\circ} \mathrm{F}$ within an hour. Thirty minutes after the injection of glucose, plasma FFA had declined from an initial concentration of 2,407 $\mu$ moles per L to $738 \mu$ moles per L, and immunologically reactive plasma insulin had risen from

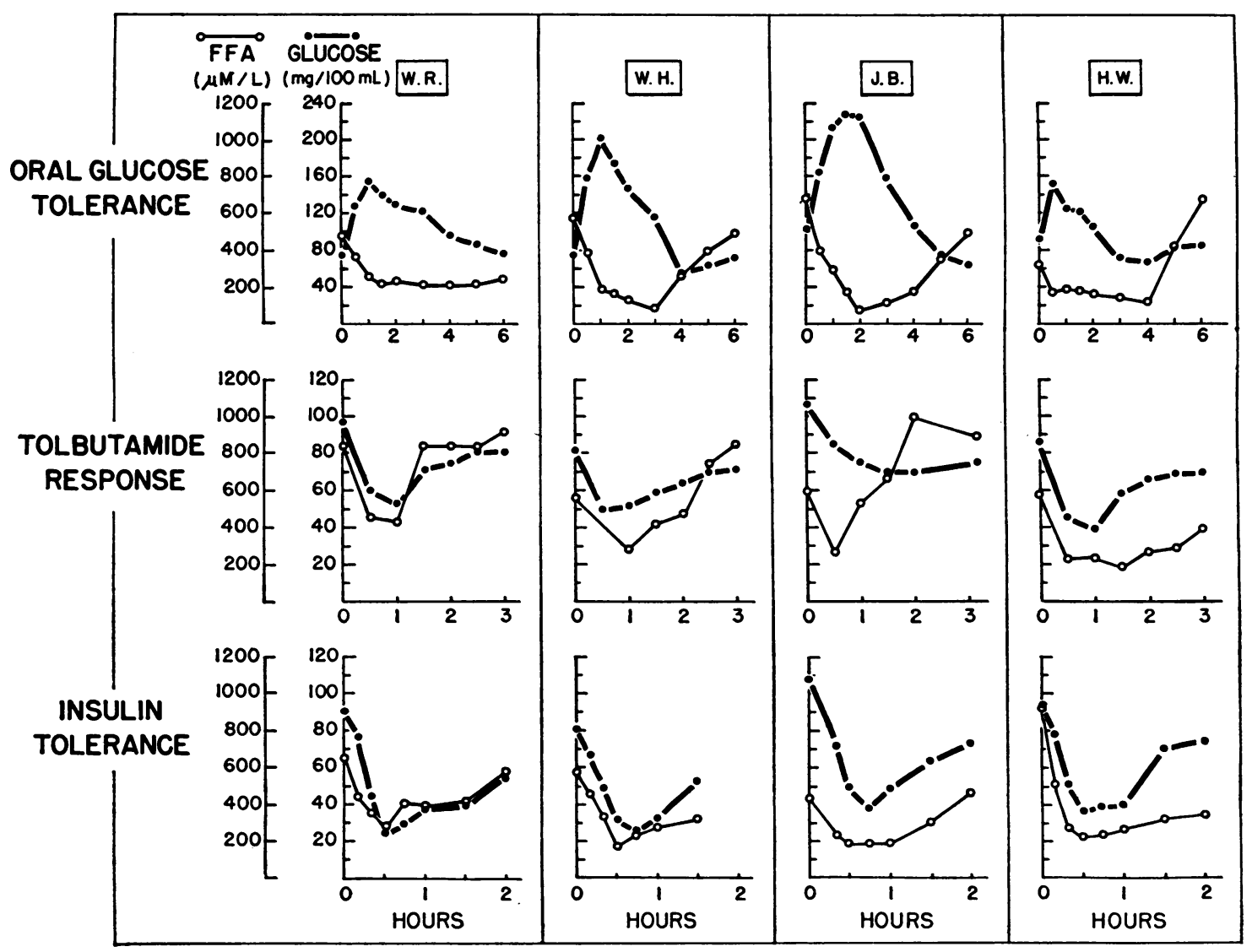

Fig. 2. Correlations between plasma glucose and plasma free fatty acids (FFA). Carbohydrate metabolism was challenged with oral glucose (Table I), iv tolbutamide (Table IV), and iv insulin (Table II) after overnight fast. 


\section{Pt. W.H.- Diet/day: Carbohydrate 295gm, Protein $110 \mathrm{gm}$, Fat $110 \mathrm{gm}$ (2610 Calories).}
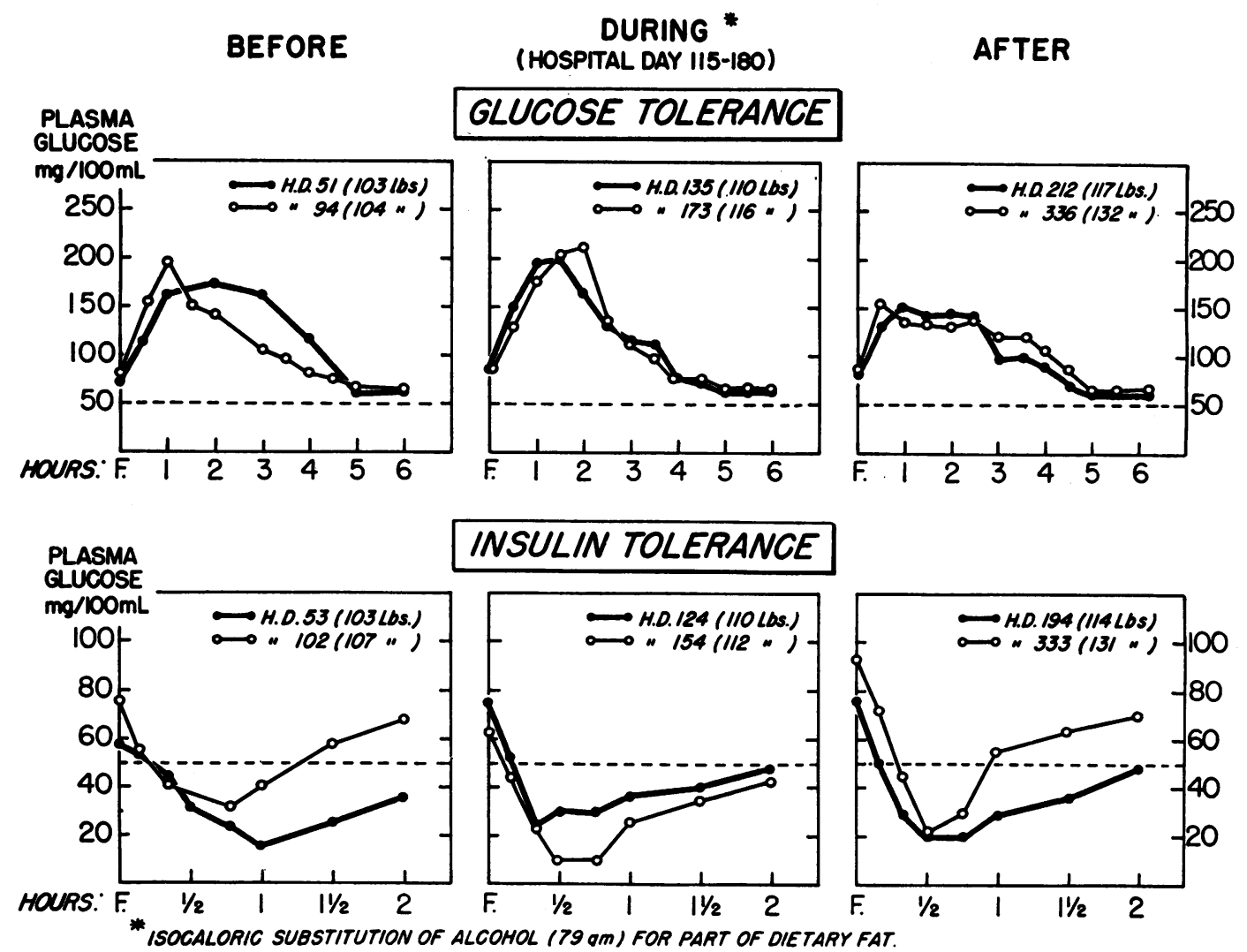

Fig. 3. Alterations in carbohydrate metabolism during chronic alcohol ingestion in Patient W. H. Absolute ethanol, $79 \mathrm{~g}$, was substituted for isocaloric quantities of dietary fat on the assumption that $1 \mathrm{~g}$ of ethanol yields 7 calories. Alcohol was added to sufficient fruit juice to disguise the taste and given in six divided feedings at 7 a.m., 9:30 a.m., 11 a.m., $1: 30$ p.m., 4 p.m., and 7 p.m. The regimen was maintained from hospital days 115 to 180 . Body weights at the time of individual tests are denoted by the numbers in the parentheses.

$0 \mu \mathrm{U}$ per $\mathrm{ml}$ to $27.5 \mu \mathrm{U}$ per ml. Plasma glucose at that time was $119 \mathrm{mg}$ per $100 \mathrm{ml}$.

Since we thought that the sequential phenomena in alcohol hypoglycemia might be definitively tabulated if the syndrome could be reproduced experimentally, alcohol was administered to the subjects.

Plasma glucose. All of the patients except H. G. and E. J. were challenged with pure ethanol. In most instances, the alcohol was given intravenously to minimize the reflex and neurohumoral effects of direct gastric irritation and to diminish the subjective response to a familiar beverage.

Earliest efforts were suggestive. O. S. and $\mathrm{W}$. Ry. were given $1.25 \mathrm{ml}$ per $\mathrm{kg}(0.99 \mathrm{~g}$ per $\mathrm{kg}$ ) of absolute ethanol dissolved in $500 \mathrm{ml}$ of isotonic saline by sustaining infusion for 1 hour after overnight fast. Blood samples were secured at the start and at the end of the infusion and at 60-minute intervals for the next 3 hours. In W. Ry., this procedure elicited plasma glucose concentrations of $76,74,65,59$, and $61 \mathrm{mg}$ per $100 \mathrm{ml}$ at $0,60,120,180$, and 240 minutes, respectively, whereas, at comparable intervals, with control infusions of saline, values for plasma glucose were 72, 72, 72, 67, and $68 \mathrm{mg}$ per $100 \mathrm{ml}$. In O. S., the 1-hour ethanol infusion yielded plasma glucose values of $77,65,61,36$, and $61 \mathrm{mg}$ per $100 \mathrm{ml}$.

The equivocal and transient results prompted revision of the administration procedure. To simulate conditions that obtain during a "drinking spree," a constant dose of alcohol consisting of 118 g ( $1 \mathrm{~L}$ of $15 \%$ ethanol in saline, vol/vol) was 
administered during an 8-hour period by constant iv infusion at the rate of $2 \mathrm{ml}$ per minute, or by five 200-ml feedings through stomach tube at 2-hour intervals. Blood samples were obtained before the start of alcohol and at 2, 4, 6, 8, 10, and 12 hours thereafter, and in most instances, 15,30 , and 60 minutes after the beginning of alcohol also. The peak levels of plasma alcohol ranged from 150 to $362 \mathrm{mg}$ per $100 \mathrm{ml}$.

When alcohol was administered in this way after overnight fast, plasma glucose declined below $50 \mathrm{mg}$ per $100 \mathrm{ml}$ in R. H. (Figure 4), W. R. (Table VI), J. B. (Figures 5 and 6 ), and W. H. (Figure 7 and Table VI). Occasionally, a 3- to 5 -mg per $100 \mathrm{ml}$ elevation of blood sugar occurred within 15 to 30 minutes after the start of alcohol administration (Figure 7 and Table VI). The hypoglycemia, characteristically, was not elicited before hour 6 , and it usually occurred after termination of the alcohol challenge. It was neither preceded nor attended by glycosuria.

Only $\mathrm{H}$. W. failed to respond with hypoglycemia to the 8-hour infusion of alcohol after overnight fast despite achieving a blood ethanol concentration of $308 \mathrm{mg}$ per $100 \mathrm{ml}$ (Table VI).

Vulnerability to the hypoglycemic effects of alcohol after overnight fast was assessed at intervals in R. H., J. B., and W. H. The 16-year-old

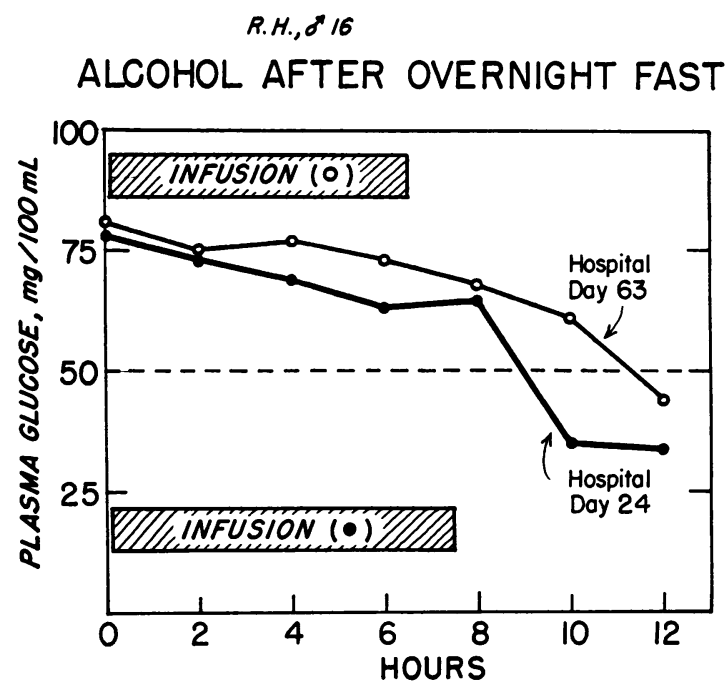

Fig. 4. ExPERIMENTAL ALCOHOL HYPOGLYCEMIA IN Patient R. H. Intravenous alcohol was administered after overnight fast on days 24 and 63 after the initial clinical episode of alcohol hypoglycemia. Infusions consisted of $15 \%$ absolute alcohol, by volume, in isotonic saline and were delivered at the rate of $2.1 \mathrm{ml}$ per minute. On each occasion, nausea and vomiting interrupted the infusion before completion of the projected 8-hour administration. The nausea subsided spontaneously within less than 3 hours, and no changes in plasma amylase were observed at any time.

schoolboy, R. H., displayed slightly improved tolerance, although interpretation is complicated by

TABLE VI

Effects of alcohol after overnight fast in patients with clinical alcohol hypoglycemia

\begin{tabular}{|c|c|c|c|c|c|c|c|c|c|c|c|c|}
\hline \multirow[b]{2}{*}{ Time } & \multicolumn{4}{|c|}{ W.H., Day 529} & \multicolumn{4}{|c|}{ W.R., Day 31} & \multicolumn{4}{|c|}{ H.W., Day 19} \\
\hline & Alcohol & $\begin{array}{l}\text { Plasma } \\
\text { glucose }\end{array}$ & FFA & Insulin & Alcohol & $\begin{array}{l}\text { Plasma } \\
\text { glucose }\end{array}$ & FFA & Insulin & Alcohol & $\begin{array}{l}\text { Plasma } \\
\text { glucose }\end{array}$ & FFA & Insulin \\
\hline $\min$ & $\underset{m l}{m g / 100}$ & $\underset{m l}{m g / 100}$ & $\underset{L}{\mu m o l e s /}$ & ${ }_{m l}^{\mu U /}$ & $\underset{m l}{m g / 100}$ & $\underset{m l}{m g / 100}$ & $\begin{array}{c}\mu m o l e s / \\
L\end{array}$ & ${ }_{m l}^{\mu U /}$ & $\underset{m l}{m g / 100}$ & $\underset{m l}{m g / 100}$ & $\underset{L}{\mu m o l e s /}$ & ${ }_{m l}^{\mu U /}$ \\
\hline 0 & 0 & 81 & 537 & 9 & 0 & 83 & 694 & 7 & 0 & 89 & 681 & 16 \\
\hline \multicolumn{13}{|c|}{ Alcohol administration, $118 \mathrm{~g} / L$ isotonic saline* } \\
\hline+15 & 44 & 84 & 637 & 8 & 10 & 81 & 625 & 12 & 10 & 93 & 522 & 14 \\
\hline+30 & 66 & 82 & 649 & 9 & 22 & 81 & 599 & 6 & 30 & 91 & 446 & 16 \\
\hline+60 & 74 & 79 & 421 & 4 & 38 & 81 & 565 & 4 & 55 & 84 & 436 & 19 \\
\hline+120 & 95 & 79 & 466 & 7 & 84 & 76 & 611 & 6 & 100 & 92 & 443 & 14 \\
\hline+240 & 130 & 79 & 521 & 5 & 162 & 80 & 676 & 8 & 180 & 95 & 428 & 8 \\
\hline+360 & 159 & 78 & 548 & 3 & 226 & 77 & 804 & 4 & 205 & 93 & 492 & 19 \\
\hline+480 & 181 & 70 & 676 & 0 & 302 & 09 & 1,065 & 11 & 308 & 96 & 426 & 3 \\
\hline+600 & 201 & 45 & 923 & 0 & 255 & 48 & 937 & 8 & 247 & 95 & 423 & \\
\hline+660 & & 35 & 1,093 & 0 & 250 & 38 & 1,409 & 5 & 238 & 96 & 432 & 12 \\
\hline+720 & 154 & 29 & 1,189 & 0 & 248 & 31 & 1,222 & 11 & 220 & 100 & 556 & 15 \\
\hline \multicolumn{13}{|c|}{ iv Glucagon, $1 \mathrm{mg}$} \\
\hline+15 & & & & & & 30 & 1,323 & 3 & 205 & 161 & 328 & 24 \\
\hline+30 & & 27 & 1,112 & $\mathbf{0}$ & & 30 & 1,560 & 3 & 193 & 169 & 269 & 24 \\
\hline+60 & 140 & 28 & 934 & $\mathbf{0}$ & & 30 & 1,360 & $\mathbf{0}$ & & 114 & 256 & \\
\hline+90 & & 28 & 944 & $\mathbf{0}$ & 234 & 31 & 1,207 & 6 & & & & \\
\hline
\end{tabular}

* Alcohol was administered during the 8 -hour interval from 0 to +480 minutes. Intravenous infusion was employed for WR. and H.W. whereas alcohol was given to W.H. in multiple feedings. 
J.8.8.75,

H.D. 34-ALCOHOL AFTER I5 HR. FAST
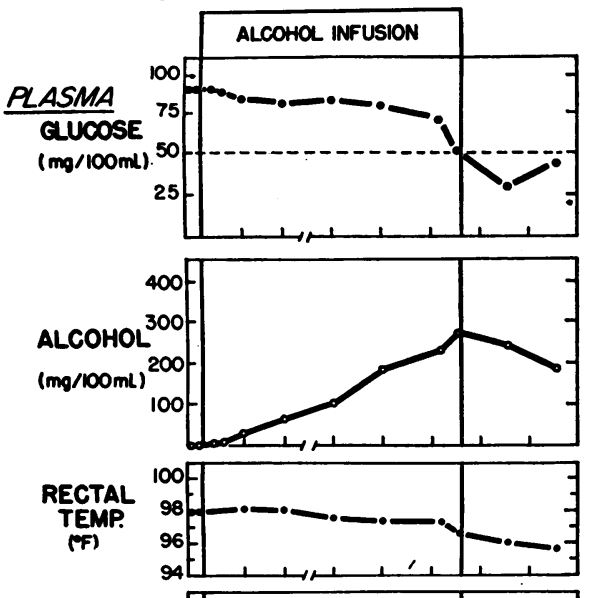

PULSE

(beots/min)
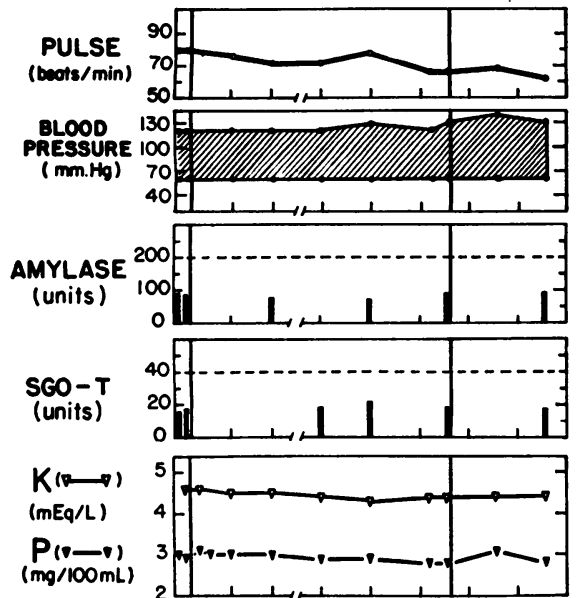

FFA

$(\mu M / L)$

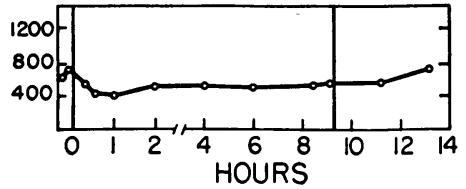

H.D. 24-ALCOHOL AFTER 69 HR. FAST
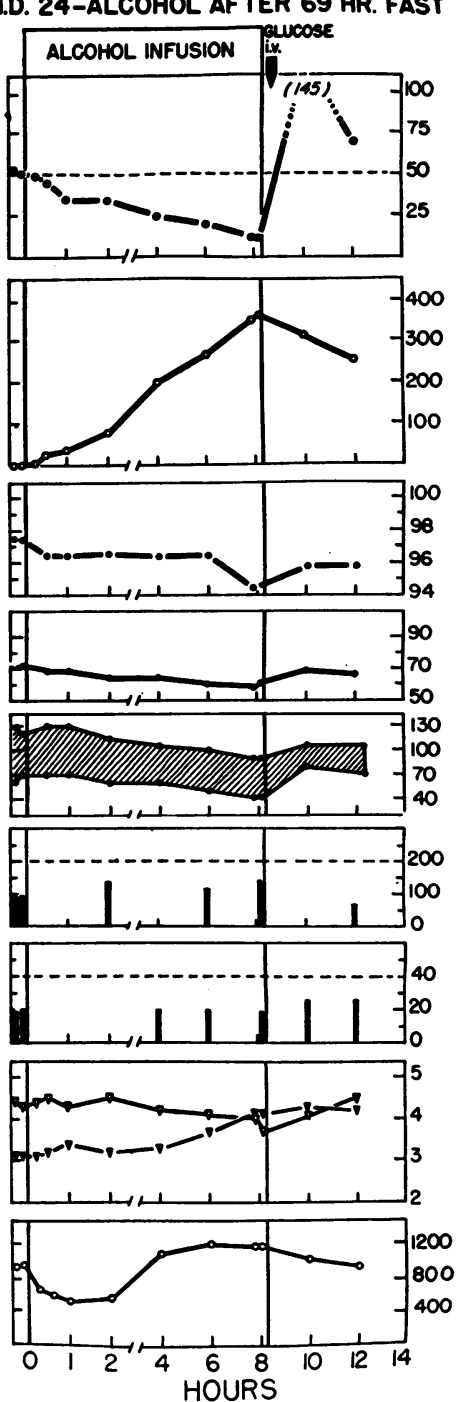

Fig. 5. Experimental alcohol hypoglycemia in Patient J. B. Infusions of absolute alcohol as a $15 \%$ solution, by volume, in isotonic saline were administered at the rate of $1.9 \mathrm{ml}$ per minute after overnight fast on day 34 and after 3-day fast on day 24. No subjective discomfort was elicited on either occasion. Because of drowsiness, the hypoglycemia on day 24 was terminated by iv injection of $60 \mathrm{ml}$ of $50 \%$ glucose. Enzymatic assay of timed urine collections during the alcohol infusion on day 34 disclosed that total urinary glucose was $17.6 \mathrm{mg}$ between hours 4 and 9 and $18.6 \mathrm{mg}$ between hours 9 and 14. On the same day, $\mathrm{pH}$ of gastric aspirate was 6.6 at the beginning of alcohol administration and 7.7 at the end.

his receiving less alcohol during the second infusion on day 63 than he received on day 24 (Figure 4). The hypoglycemic potential of alcohol in J. B. and W. H. was not appreciably attenuated. In J. B., on day 34 (Figure 5) and day 131 (Figure 6), and in W. H., on day 343 (Figure 7) and day 529 (Table VI), identical challenges with al- cohol after overnight fast elicited equal degrees of hypoglycemia.

To evaluate the role of antecedent diet, J. B. (Figure 5) and W. H. (Figures 7 and 8) were also challenged with alcohol after a 3-day fast. The hypoglycemic effects of alcohol were strikingly enhanced. Although fasting, per se, had re- 
duced blood sugar in these patients, alcohol effected a further precipitous decrement that began almost immediately. Ultimate nadir values for plasma glucose of 10 to $35 \mathrm{mg}$ per $100 \mathrm{ml}$ were achieved. In J. B., drowsiness necessitated giving exogenous glucose at the height of the hypoglycemia (Figure 5). In W. H., plasma glucose rose spontaneously with the declining blood alcohol (Figure 7).

The hypoglycemic effectiveness could be offset, at least in part, by cortisone. When W. H. was receiving $75 \mathrm{mg}$ of oral cortisone every 8 hours during fasting on days 601 to 604 , oral ethanol on day 604 did not reduce plasma glucose to concentrations below $51 \mathrm{mg}$ per $100 \mathrm{ml}$ (Figure 8).

Intravenous glucagon, $1 \mathrm{mg}$, was given four times to W. H., twice to J. B., and once to W. R. at the time of alcohol hypoglycemia. Under these conditions, glucagon did not alter blood sugar as shown in the examples in Figures 6 and 8 and Table VI, but it raised plasma glucose 25 to $75 \mathrm{mg}$ per $100 \mathrm{ml}$ in the same subjects when administered after control studies in which isotonic saline had been infused without alcohol (Figure 6).

The hormonal actions of glucagon apparently are not blocked by alcohol per se. In H. W., blood sugar was not lowered by the 8-hour infusion of alcohol, and glucagon effected a brisk rise in plasma glucose (Table VI). The ineffectiveness of glucagon during alcohol hypoglycemia may merely indicate that mobilizable hepatic glycogen has been exhausted.

Physiological adjustments to experimental alcohol hypoglycemia. Experimental induction of alcohol hypoglycemia did not elevate pulse rates above 90 beats per minute in any subject, and in

( J.B. 8,75$)$

H.D. 131 - ALCOHOL AFTER 18 HR. FAST

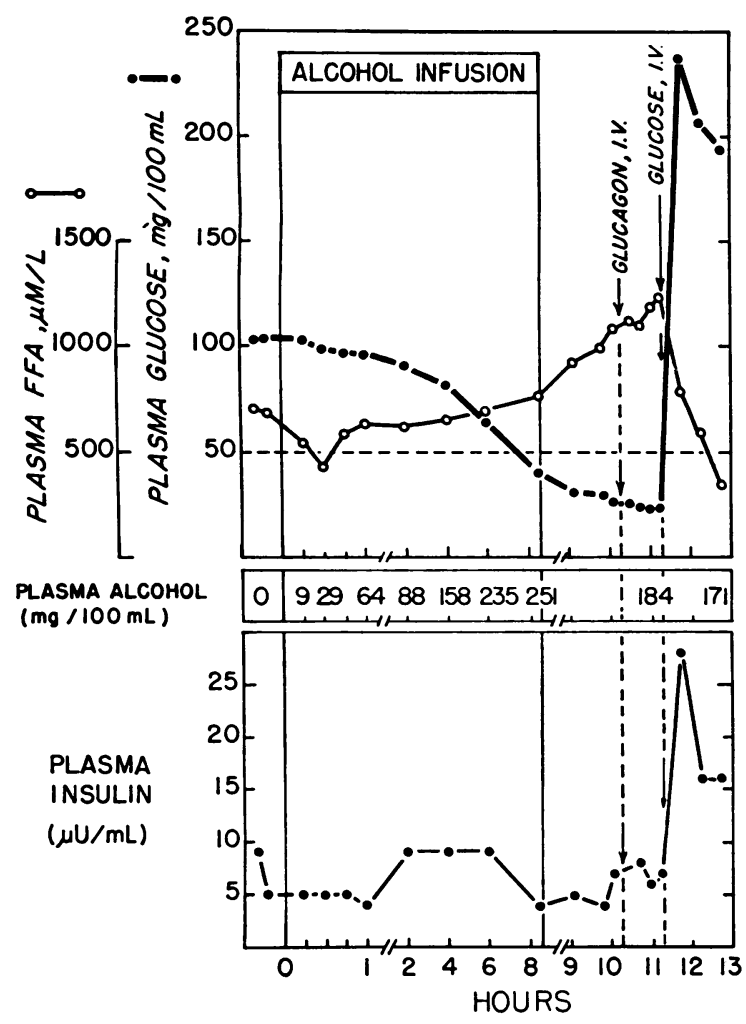

H.D. 140 - SALINE AFTER 15 HR. FAST

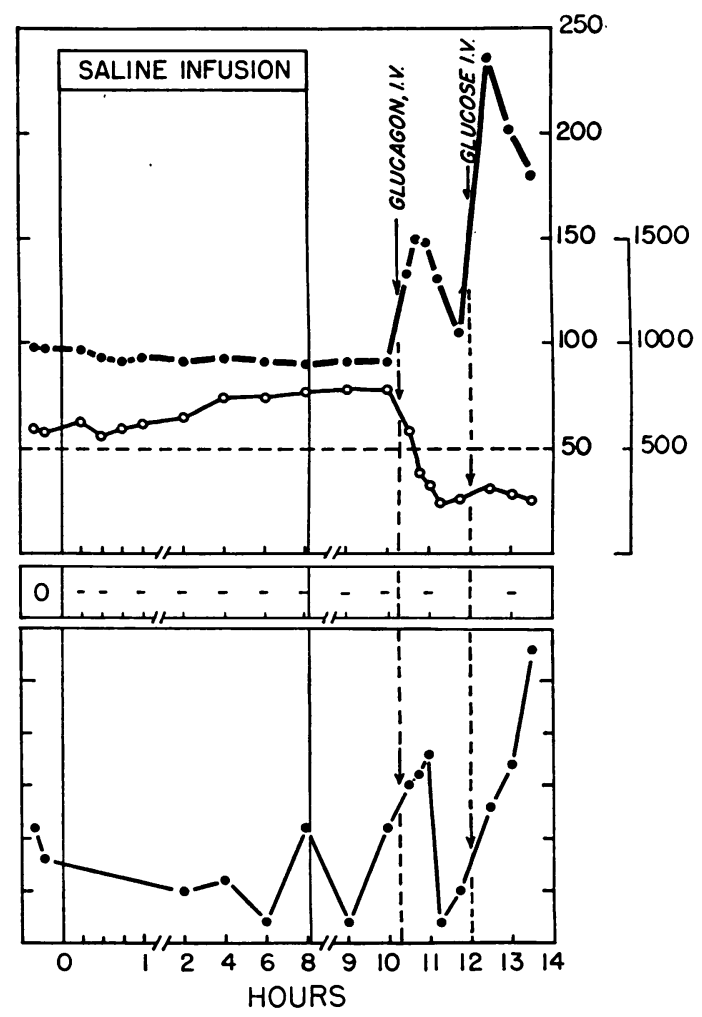

Fig. 6. Persistent vulnerability to alcohol hypoglycemia in Patient J. B. Alcohol was infused after overnight fast on day 131 under conditions similar to those described in Figure 5. Control studies were performed by infusing equal quantities of isotonic saline on day 140. During postinfusion periods, separate iv injections of glucagon, $1 \mathrm{mg}$, and glucose, $60 \mathrm{ml}$ of a $50 \%$ solution, were administered as indicated by vertical arrows. Plasma specimens were diluted $1: 5$ for insulin immunoassay. 
Whis:?

H.D. 343 - ALCOHOL AFTER 19 HR. FAST $\quad$ H.D. 348 - ALCOHOL AFTER 74 HR. FAST
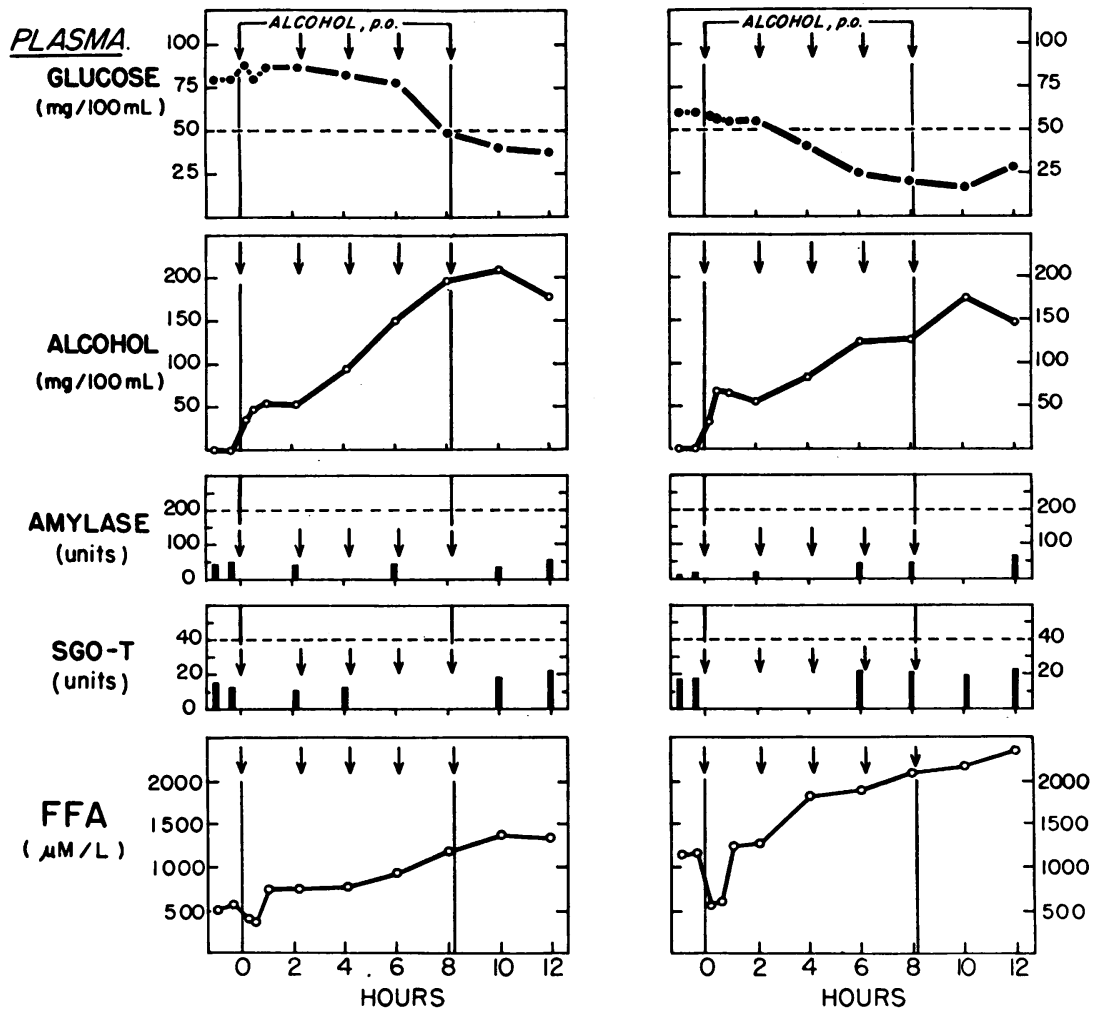

Fig. 7. Relationship between fasting and experimental alcohol hypoglycemia in Patient W. H. Absolute alcohol, $15 \%$ by volume in isotonic saline, was administered via gastric tube at intervals, as indicated by vertical arrows. Each feeding consisted of $200 \mathrm{ml}$ of the $15 \%$ solution. Except for objections to the nasogastric tube, no subjective discomfort was expressed. Behavioral changes were confined to mild increases in garrulity.

some instances, profound reductions of blood sugar were effected without any alterations in cardiac rate (Figure 5). Rectal temperature was invariably reduced, and both diastolic and systolic blood pressures were usually lowered (Figures 5 and 8 ).

To demonstrate a dissociation between the hypoglycemic potential of alcohol and certain of these physiological phenomena, repetitive subcutaneous doses of atropine were given during the administration of ethanol to $\mathrm{W}$. $\mathrm{H}$. on day 371 after a 3-day fast (Figure 8). Oral ethanol reduced plasma glucose to concentrations below 40 $\mathrm{mg}$ per $100 \mathrm{ml}$ from hour 4 onward, although rectal temperature and pulse rate were maintained above $98^{\circ} \mathrm{F}$ and 90 beats per minute, respectively. The atropine did not prevent reduction of blood pressure.
Biochemical concomitants of experimental alcohol hypoglycemia. Serial assays for the plasma enzymes SGO-T and amylase disclosed no characteristic progression, and experimental alcohol hypoglycemia could be induced without any appreciable changes in these parameters (Figures 5 and 7$)$.

In three experiments in W. H., two in J. B., and one in W. R., plasma levels of phosphorus and potassium were assayed as indexes of glucose utilization. The findings in J. B., typical of all observations, are presented in Figure 5. Induction of hypoglycemia was accompanied by a modest rise in phosphorus and a small reduction of plasma potassium.

In every experiment with the 8-hour administration technique, plasma specimens were ana- 
lyzed for FFA as a more sensitive index of peripheral insulin-like effects. A biphasic pattern was observed most frequently (Figures 5 to 8 and Table VI). Alcohol produced transient reductions of plasma FFA to values that were 20 to $53 \%$ (average 35\%) lower than the initial concentrations. The decrements were usually confined to the first hour and were not observed during control studies with saline. Nadir FFA levels oc- curred when plasma alcohol concentrations ranged from 21 to $73 \mathrm{mg}$ per $100 \mathrm{ml}$. After this early lowering of FFA, the continued delivery of alcohol was accompanied by slow, progressive elevation of plasma FFA to maxima that were 120 to $227 \%$ of control values. The peaks occurred 8 to 12 hours after the start of the experiments and were not always coincident with the peak values for plasma alcohol. Only H. W. deviated from this

THE EFFECT OF ALCOHOL AFTER 3 DAY FAST
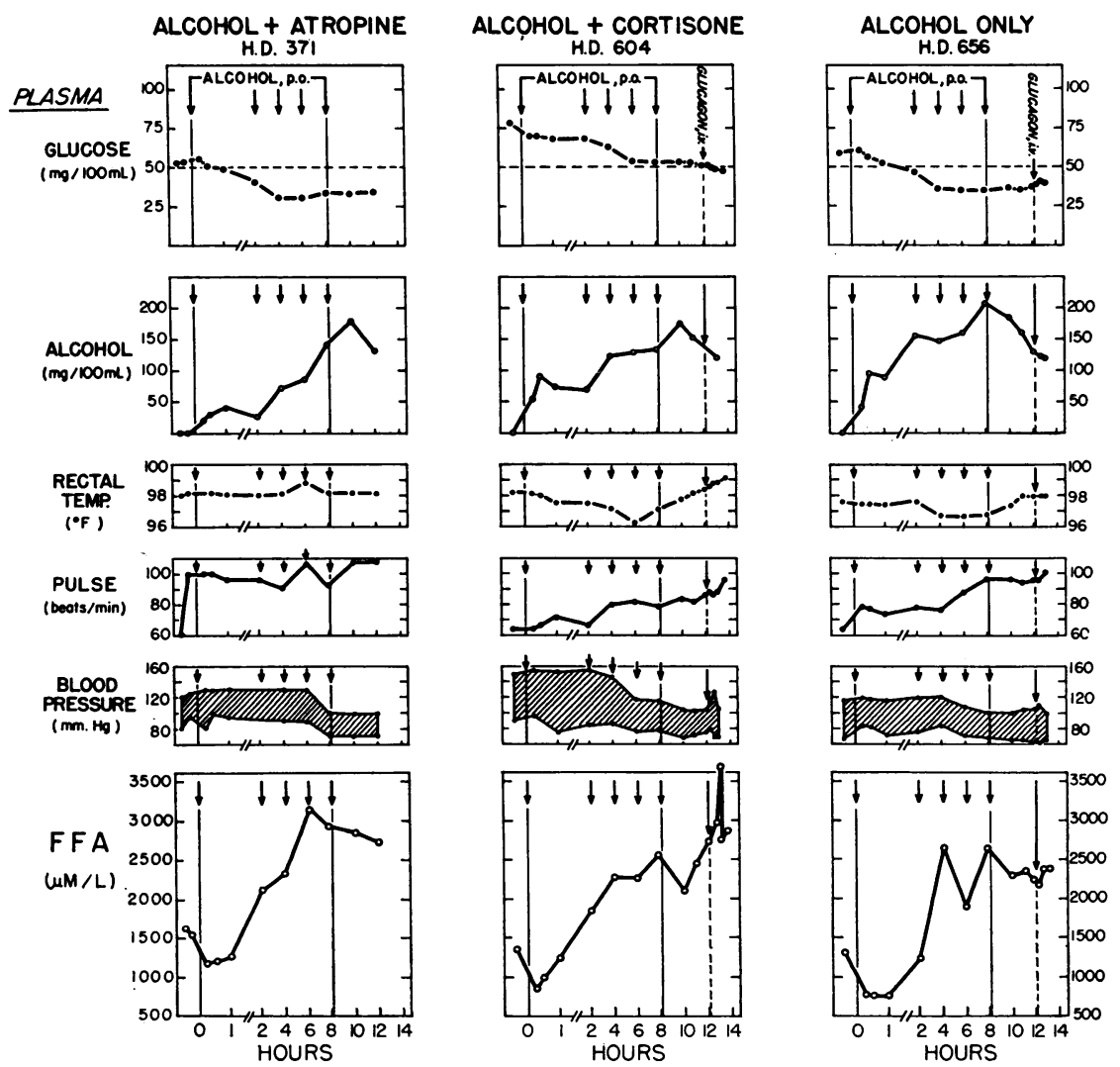

Fig. 8. Persistent vulnerability to alcohol hypolycemia in Patient W. H. And attempts at pharmacological modification. Alcohol was administered orally as described in Figure 7. Atropinization was effected on day 371 by injecting $2 \mathrm{mg}$ of atropine sulfate subcutaneously 90 minutes before alcohol feedings, and it was maintained by supplemental injections of $1.2 \mathrm{mg}$ of atropine sulfate 15 minutes, 6 hours, and 9 hours after the first dose of alcohol. (The two control values for each parameter on day 371 depict measurements obtained immediately before and $80 \mathrm{~min}$ utes after the initial injection of atropine.) To assess the effects of cortisone on day 604 , cortisone acetate, $75 \mathrm{mg}$ every 8 hours, was given throughout the prior 3-day fast, and immediately before the first and the last alcohol feeding. No attempts were made to modify the response to alcohol on day 656 , and the experiment was designed for intercomparison with the results obtained under similar conditions on day 348 (cf. Figure 7). The vertical bars labeled "glucagon, iv" denote the iv injection of 1 mg of glucagon. 
pattern (Table VI). Her reduction of plasma FFA was sustained throughout the ethanol infusion. At the same time, normoglycemia was preserved.

Lieber and associates have previously reported that ethanol after overnight fast can lower plasma FFA in normal subjects without affecting blood sugar $(41,42)$. In these studies, when hypoglycemia was induced by ethanol after overnight fast, the decrement in FFA antedated the hypoglycemia by 3 to 7 hours, and even when alcohol was given after a preliminary 3-day fast, the downward trend of FFA was arrested and reversed despite continuing reductions of blood sugar (Figures 5 to 8).

Plasma insulin during ethanol administration. In a limited number of studies, all specimens of plasma were examined for insulin by immunoassay. Initial analyses (Figures 5 and 7) were performed with tenfold dilutions of plasma. No increments in immunologically reactive plasma insulin were detectible, although immunoassay with 1:10 dilutions of plasma from the same subjects disclosed rises in insulin after oral glucose or iv tolbutamide. To enhance analytical sensitivity, subsequent measurements were performed with $1: 5$ dilutions of plasma. Even under these conditions, none of the plasmas secured during the experimental alcohol hypoglycemias that are listed in Table VI contained insulin in excess of $12 \mu \mathrm{U}$ per $\mathrm{ml}$. Within methodological limitations, systematic increments in immunologically reactive insulin could not be demonstrated.

Glucagon did not affect plasma insulin when given at the time of alcohol hypoglycemia, whereas insulin rose with the elevation of blood sugar when glucagon was given during normoglycemia (Figure 6 and Table VI). In J. B., the single subject in whom it was examined (Figure 6), iv glucose during experimental alcohol hypoglycemia produced a brisk rise in immunologically reactive insulin and a prompt reduction in the levels of plasma FFA. The changes did not differ substantially from the alterations in plasma insulin and FFA effected by similar quantities of iv glucose during control studies with saline (Figure 6). Apparently, the potentialities for the mobilization of pancreatic insulin and the response of adipose tissue to glucose flux are preserved during experimental as well as clinical alcohol hypoglycemia.

\section{DISCUSSION}

The nine patients admitted to Boston City Hospital in hypoglycemic coma after alcohol ingestion between 1960 and 1962 constitute $0.015 \%$ of all of the admissions during this period. The entity apparently is uncommon, but not rare. Since the nine were of diverse racial and ethnic backgrounds, the incidence may not be unique, but could equally obtain in any institution that serves a comparable socio-economic group. The syndrome may be considered most profitably in terms of the basal carbohydrate metabolism of these subjects and the modifications that were produced by the introduction of alcohol.

Tests of carbohydrate metabolism. Severe liver disease was not present in any patient. Despite heavy alcoholism, most of them exhibited relatively well-preserved hepatic function at admission, and such abnormalities as obtained were frequently rectified during hospitalization. Three of the nine had a family history of diabetes mellitus, although none had glycosuria. Classical endocrinopathy was not present. Two displayed subtle disturbances in pituitary-adrenal interrelationships. Basal steroid excretion was low in J. B., although responsiveness to Metopirone and ACTH obtained, whereas basal steroid excretion was higher in W. H., although faulty response to Metopirone showed diminished corticotropin reserve. All were lean, but none exhibited the inanition and nutritional defects cited in some of the previous reports of alcohol hypoglycemia (3, 4, 12). Clinical evidence for islet-cell tumor was lacking, and even in Patient W. Ry., whose indexes were most suspicious, immunoassay values for fasting plasma insulin were normal, exercise after 3-day fast did not accentuate the hypoglycemia, and exploratory laparotomy, including excision of the tail of the pancreas, did not disclose any lesion.

For most, there were no gross abnormalities in any of the hepatic, endocrine, or nutritional factors implicated in the classical forms of spontaneous or endogenous hypoglycemia $(43,44)$. Nonetheless, certain aspects of their carbohydrate tests suggest that endogenous glucose homeostasis may have been marginally balanced.

First, although all nine maintained normal blood sugar after overnight fast, seven displayed some impairment in the disposition of oral glucose loads. 
In these seven, equilibruim considerations demand that the maintenance of fasting normoglycemia with reduced glucose utilization requires only reduced rates of endogenous glucose production (45). Second, all nine responded with excessive lowering of blood sugar or deficient counterregulation to at least one of the procedures that acutely (insulin, tolbutamide), or chronically (starvation) challenged the fasting equilibrium between endogenous glucose production and glucose utilization. Direct immunoassay of plasma confirmed that these phenomena were not due to abnormal persistence of circulating insulin. They are further evidence for reduced basal glucose production.

Even superficial analysis indicates that these subtle limitations in the regulation of fasting blood sugar cannot be ascribed to a common etiology. The impaired autonomic response to insulin hypoglycemia in some of the chronic alcoholics, and even in two with normal pituitary-adrenal interrelationships, warrants consideration. It could have reflected a neuropathic consequence of marginal antecedent diet, or an expression of diabetic neuropathy in those patients with coexisting oral glucose tolerances of the diabetic type. We can speculate that alcohol per se may directly participate, and the premise is reinforced by the experience in the one alcoholic in whom isocaloric substitution of alcohol was instituted. Since alcohol can effect acute release of catecholamines (46-48) and serotonin $(48,49)$ from preformed tissue stores, and since repletion of such stores is not immediate $(31,48,50,51)$, mobilizable neurohumors could be compromised by chronic ethanol addiction. The finding that alcohol acutely enhances the urinary excretion of catecholamines in the rat, but that chronic ethanol feeding results in a diminished urinary output of epinephrine and norepinephrine (47) suggests this. The role of tonic autonomic activity in fasting blood sugar homeostasis has not yet been clarified. The reported induction of acute hypoglycemia in the rat after transection of the spinal cord (52) suggests that tonic neural influences may be of significance.

None of these chronic factors can explain the abnormal tests in the 16-year-old schoolboy. Diagnostic application of iv tolbutamide has been too limited to determine if the prolonged hypoglycemia in his initial test was due to a transient pancreatic, hepatic, or endocrine insult incurred during the acute alcoholic debauch. Regardless of such evanescent lesions, his poor tolerance to fasting 2 months after the clinical episode of alcohol hypoglycemia suggests that his endogenous equilibrium between glucose production and utilization was also tenuous. Possibly, precarious equilibration constitutes the physiological norm for this age group, if active growth were to preempt endogenous amino acids for anabolism and restrict their delivery to the liver for gluconeogenesis.

Despite possibly diverse mechanisms, all nine patients displayed some limitation in their reserve for regulation of endogenous carbohydrate metabolism. Until more cases have been subjected to comparably detailed dissection, we cannot infer such marginal balance in all instances of clinical alcohol hypoglycemia. One may suggest, however, that the vulnerability to various forms of hypoglycemic challenge in this group may have rendered them especially susceptible to the hypoglycemic actions of alcohol.

Experimental alcohol hypoglycemia. Seven patients were challenged with pure ethanol. In five of them, ethanol after overnight fast reduced plasma glucose to levels below $50 \mathrm{mg}$ per $100 \mathrm{ml}$ and reproduced all other features of the clinical syndrome. As will be documented in a subsequent report, hypoglycemia can also be elicited with alcohol in normal subjects (13), although a minimum of 2 to 3 days fasting is necessary. The hypoglycemic potential of ethanol independent of congeners or denaturants is clearly established. Field and Williams reached similar conclusions in their concurrent and independent studies of the effects of alcohol upon blood sugar (53).

Several aspects of our experiences with experimental alcohol hypoglycemia warrant recapitulation because of their possible relevance to mechanisms.

1) When induced after overnight fast, hypoglycemia occurred late in alcohol administration, and frequently, when blood alcohol concentration was declining, suggesting that the phenomenon may be related to some aspect of the intracellular metabolism rather than the extracellular concentration of alcohol. Since normoglycemia followed most of the disposition of alcohol, the presence of some alcohol may be necessary to maintain hypoglycemia. 
2) When induced after a 3-day fast, hypoglycemia was more pronounced and acute. This suggests that it is favored when peripheral demands are adapted to products of fat metabolism (54) and intrahepatic glucose flux is derived almost entirely from gluconeogenesis (55). Although other interpretations are possible, the fact that hypoglycemia was attenuated by premedication with pharmacological quantities of cortisone supports the hypothesis that there is an inverse correlation between the adequacy of gluconeogenesis and the vulnerability to alcohol hypoglycemia.

3) Judged by serum SGO-T, experimental alcohol hypoglycemia was not attended by acute hepatocellular toxicity. Since glucagon did not raise blood sugar during alcohol hypoglycemia, although it did during control studies of comparable duration, one infers that the hypoglycemia occurred when hepatic glycogen stores had been exhausted through activated glycogenolysis or impaired glycogenesis. Hypoglycemia from exogenous (56) and endogenous (57) insulin may be terminated by glucagon.

4) Experimental alcohol hypoglycemia was not attended by the changes that are characteristic of augmented peripheral glucose utilization in such inferential indexes as plasma $\mathrm{K}, \mathrm{P}$, and FFA. Although alcohol occasioned an early fall in plasma FFA, the induction of alcohol hypoglycemia was temporally dissociated from this decline and coincided with rising levels of plasma FFA. In the same subjects, the induction of hypoglycemia by exogenous insulin or tolbutamide elicited parallel reductions in blood sugar and FFA.

5) No evidence for primary pancreatic mediation could be assembled. Changes in plasma amylase were inconstant; vagal blockade with atropine did not alter the hypoglycemic response, and induction of alcohol hypoglycemia in Subject J. B. with histamine-refractive achlorhydria precludes activation of islet-cell secretions through stimulation of gastric acidity (58) and secretin $(59,60)$ by alcohol $(61)$. Direct immunoassay of all plasma specimens obtained before and after the experimental alcohol hypoglycemia failed to disclose systematic changes in circulating insulin. Not all biologically active "insulin-like" material need be immunologically reactive, however (62, 63). Even for immunologically reactive insulin, the concentrations in peripheral blood need not validly reflect the concentrations in the portal vein (64), since a varying proportion may be abstracted or sequestered during transhepatic passage $(65,66)$.

6) In some patients, the blood-sugar lowering effect of alcohol after overnight fast persisted despite prolonged alimentation and rehabilitation in a controlled environment. Apparently, perpetuation of extreme sensitivity to alcohol hypoglycemia requires neither marginal diet nor repetitive exposure to alcohol.

General comments. The present studies have demonstrated that alcohol hypoglycemia constitutes a specific clinical syndrome, one that justifies inclusion in those detailed listings of the hypoglycemic states from which it has been heretofore excluded. The ease with which it could be reproduced in some of the present subjects, under experimental conditions that simulated their outside drinking patterns, suggests that at least these patients experienced alcohol hypoglycemia far more frequently than their record of hospital admissions indicates.

Nosologically, alcohol hypoglycemia must be classified as a form of exogenous hypoglycemia. It arises after the interruption of the fasting equilibrium by a pharmacological agent, and it is especially likely in those subjects in whom the endogenous balance between glucose production and utilization is already precarious. The role of alcohol may thus be assessed: the intact molecule probably exerts those supratentorial actions that the term "alcohol inebriation" encompasses (49); oxidation of the molecule occasions changes in pyridine nucleotides $(67,68)$ that can alter more catholic metabolic interactions $(69,70)$; and the oxidative yield of 2 -carbon fragments $(71,72)$ provides useful calories that can obviate fulfilling fasting metabolic requirements from endogenous sources. The precise aspect of alcohol metabolism that may be implicated in alcohol hypoglycemia remains to be elucidated. These studies have provided a framework of reference for the inquiries that will be reported in subsequent communications.

\section{SUMMARY}

1. During a single 2-year period (1960-1962), eight chronic alcoholics and one 16-year-old schoolboy entered Boston City Hospital with hypoglycemic coma following alcoholic debauch. Carbo- 
hydrate regulation was challenged with oral glucose, exogenous insulin, tolbutamide, and fasting to delineate a metabolic profile that might be characteristic of the group. All responded abnormally to at least one of the challenges, thus indicating that the endogenous equilibrium between glucose production and glucose utilization was marginally balanced in all of them. In some of the patients, the tests improved during prolonged observation on a metabolism ward. The defects in glucose homeostasis could not be ascribed to a common etiology, although an exacerbating influence of alcohol was demonstrated in one patient.

2. The acute episode of clinical alcohol hypoglycemia was documented in detail in one patient. In six patients, attempts were made to reproduce the syndrome by the experimental exhibition of pure ethanol. All facets could be reproduced in this way.

3. Significant lowering of plasma glucose was effected in six of seven patients when alcohol was administered after overnight fast. In five of these, concentrations below $50 \mathrm{mg}$ per $100 \mathrm{ml}$ were achieved. A lag phase was interposed between the sustained elevation of plasma alcohol and the eventual fall in blood sugar. The early decline in plasma free fatty acids (FFA), which ethanol induces, was temporally dissociated from the reduction of plasma glucose. The hypoglycemic response was more promptly effected and markedly enhanced when alcohol was administered after longer periods of fasting. In both situations, experimental alcohol hypoglycemia was induced at blood levels of alcohol that were moderate and well below the prerequisite range for alcoholic coma.

4. Experimental alcohol hypoglycemia was not accompanied by elevations of plasma glutamicoxalacetic transaminase or amylase. It could not be interrupted by glucagon. With the induction of alcohol hypoglycemia, those changes in plasma inorganic phosphorus and FFA that connote heightened peripheral utilization of glucose were not observed. Within the limits of analytical techniques, systematic increments in circulating immunologically reactive insulin could not be detected.

5. Exhibition of exogenous glucose in clinical as well as in experimental alcohol hypoglycemia was followed by a reduction of FFA and a rise in plasma insulin, indicating that the potentialities for the mobilization of pancreatic insulin and the response of adipose tissue are preserved.

6. In some of the patients, extreme sensitivity to the blood-sugar lowering actions of alcohol persisted despite adequate alimentation and prolonged rehabilitation in a controlled environment.

\section{APPENDIX}

Patients. Brief characterizations of individual patients are presented below. Except where indicated, family histories were negative for metabolic diseases, and tests of endocrine status were within normal limits.

1) H. W.: 32-year-old white, divorced female, former secretary, and "heavy drinker since the age of 19," who was brought to the hospital after a friend with whom she was staying was unable to awaken her one morning. She had been imbibing excessively for 1 week before admission, and food intake had been negligible during this interval. Within the preceding 3 years, she had had at least four other admissions to Boston City Hospital and to other hospitals in the Boston area for "low blood sugar and coma." Plasma glucose at admission was 6 $\mathrm{mg}$ per $100 \mathrm{ml}$

2) R. H.: 16-year-old white schoolboy who had consumed "about two-thirds" of a bottle of bonded whiskey on the afternoon of the day of admission while on a fishing trip with friends. His food intake had been limited to breakfast on that day, and he was discovered in a comatose state in the early evening. Previous consumption of alcoholic beverages had been limited to "two or three beers on week ends." His maternal grandmother had diabetus mellitus. Blood sugar at admission was 27 $\mathrm{mg}$ per $100 \mathrm{ml}$.

3) O. S.: 67-year-old widowed Negro male, former laborer, who lived alone and had been imbibing " $\frac{1}{2}$ to 1 pint of whiskey or gin per day" for most of his adult life. On the day before admission, he had eaten two full meals and consumed 1 pint of gin. $\mathrm{He}$ awoke the next morning "feeling weak and unsteady," drank more gin, and was discovered in comatose state by his landlord at 6:00 p.m. One of his three siblings had diabetes mellitus. Blood sugar at admission was $15 \mathrm{mg}$ per 100 $\mathrm{ml}$.

4) E. J.: 35-year-old Negro housewife with agnogenic epilepsy since childhood, who had been drinking heavily on a "spree" basis for 9 years. The day before admission, she had consumed " 1 to 2 pints of gin," but had also eaten 3 full meals. She had retired at 10 p.m. because of undue fatigue and was unresponsive when her family discovered her on the floor at 6 a.m. of the following day. Blood sugar at admission was $34 \mathrm{mg}$ per 100 $\mathrm{ml}$.

5) W. R.: 60-year-old divorced Negro male, janitor, who lived alone and customarily ate little but drank "substantial" quantities of wine and whiskey. On the day before admission, he had eaten 2 sandwiches and imbibed as usual. He reported for work the following morning and moved ash-cans, although his employer felt that he appeared "drunk." $\mathrm{He}$ lapsed into coma after several 
hours (during which no alcoholic beverages were consumed), and he was brought to the hospital with a plasma glucose of $31 \mathrm{mg}$ per $100 \mathrm{ml}$.

Twenty-four hour urinary excretions of 17 -ketosteroids (17-KS) and 17-ketogenic steroids (17-KGS) were 5.4 $\mathrm{mg}$ and $10.4 \mathrm{mg}$, respectively, and these rose to 9.1 and $24.3 \mathrm{mg}$, respectively, after $25 \mathrm{U}$ of ACTH. Challenge with Metopirone, however, induced anorexia, nausea, and reduced $17-\mathrm{KS}$ to $3.5 \mathrm{mg}$ per 24 hours and $17-\mathrm{KGS}$ to 7.1 $\mathrm{mg}$ per 24 hours. (In males, the normal values for urinary steroids obtained by these methods are 9 to $22 \mathrm{mg}$ per 24 hours for $17-\mathrm{KS}$ and 8 to $25 \mathrm{mg}$ per 24 hours for 17 $\mathrm{KGS})$. Values for protein-bound iodine (PBI), 24-hour $\mathrm{I}^{131}$-uptake, and urinary follicle-stimulating hormone $(\mathrm{FSH})$ were within normal limits.

6) H. G.: 81-year-old white male, "social drinker," who usually confined his alcoholic intake to "three ounces of whiskey per night as a sedative." The day before admission, he had eaten substantial breakfast, but omitted lunch and supper while consuming " $1 \frac{1}{2}$ pints of bottled whiskey." He was found in his room on the following afternoon and brought to the hospital unconscious with a plasma glucose of $31 \mathrm{mg}$ per $100 \mathrm{ml}$.

7) W. Ry.: 42-year-old white male, itinerant kitchen helper, who had been a chronic alcoholic since the age of 22 and had been consuming an average of "a fifth of whiskey, 3 to 4 quarts of beer," and a variable amount of port wine per day for the 5 months preceding hospitalization. During this interval, his food intake had been minimal, and his weight had declined from "135 to 118 pounds." On the day before admission, he had eaten a substantial breakfast and thereafter consumed chiefly beer until his arrest for vagrancy that evening. He was not fed in jail, and lapsed into progressive coma during confinement in his cell. On admission to the hospital the following morning, values for blood and cerebrospinal fluid glucose were 24 and $15 \mathrm{mg}$ per 100 $\mathrm{ml}$, respectively. His mother had diabetes mellitus.

8) J. B.: 75-year-old white male, retired merchant marine engineer, who lived alone and customarily restricted his alcoholic imbibition to " 3 to 4 beers and 1 ounce of whiskey in the neighborhood bar with friends." The day before admission, he had eaten his regular meals, but in addition, he had consumed "a half-pint of whiskey" before retiring. Upon awakening the following morning, he "felt lightheaded" and took "several additional sips." He was discovered in a stuporous state by his landlord and brought to the hospital at 10 p.m. Values for plasma and cerebrospinal fluid sugar were $5 \mathrm{mg}$ per $100 \mathrm{ml}$ and $8 \mathrm{mg}$ per $100 \mathrm{ml}$, respectively.

Analysis of urines collected during hospitalization disclosed subnormal steroid output. Basal 24-hour values for 17-KS and 17-KGS were 3.8 and $5.7 \mathrm{mg}$, respectively. However, Metopirone, as well as ACTH, effected enhanced steroid excretion. In response to ACTH, 17-KS rose to $8.5 \mathrm{mg}$ per 24 hours and 17-KGS rose to 17.9 mg per 24 hours. Similarly, during challenge with Metopirone, 24-hour urinary excretions of $17-\mathrm{KS}$ and 17-KGS were increased to $9.5 \mathrm{mg}$ and $18.8 \mathrm{mg}$, respectively. Values for PBI, 24 hour $\mathrm{I}^{131}$-uptake, and urinary FSH were within normal limits.

9) W. H.: 52-year-old white male, schizophrenic recluse, who lived alone and whose relatives had been providing him with 1 quart of commercial port wine each day since the age of 20 . There had been no prior medical difficulties. On the day of admission, he was discovered in a comatose state, and observers estimated that he had eaten nothing for 24 hours before admission and that his alcohol uptake had consisted of "approximately $\frac{1}{2}$ gallon of bottled wine." Blood sugar and cerebrospinal fluid sugar after admission were $21 \mathrm{mg}$ per $100 \mathrm{ml}$ and $8 \mathrm{mg}$ per $100 \mathrm{ml}$, respectively.

Tests of liver function. Initial values are summarized below. Functional tests were obtained shortly after admission, whereas liver biopsies were usually obtained at a later date. To facilitate correlations, the hospital day on which biopsy was performed is indicated by the number in brackets.

\begin{tabular}{|c|c|c|c|c|c|c|c|}
\hline Patient & BSP* & Biliburin & $\begin{array}{l}\text { Alk. } \\
\text { phos. }\end{array}$ & SGO-T & $\begin{array}{l}\text { Ceph. } \\
\text { floc. }\end{array}$ & Amylase & Biopsy† \\
\hline & $\%$ & & & & & & \\
\hline H.W. & 3.4 & 0.7 & 1.2 & 54 & $4+$ & 112 & Mild fatty changes $[1]$ \\
\hline R.H. & 1.4 & 0.6 & 3.0 & 24 & 0 & 129 & \\
\hline O.S. & 8.8 & 0.8 & 1.5 & 64 & $1+$ & & Essentially normal liver [24] \\
\hline E.J. & 4.9 & 0.6 & 1.9 & 43 & $2+$ & 112 & Essentially normal liver [44] \\
\hline W.R. & 11.2 & 0.7 & & 20 & & 90 & $\begin{array}{l}\text { Essentially normal liver ex- } \\
\text { cept for many vacuolated } \\
\text { nuclei }\end{array}$ \\
\hline H.G. & 7.6 & 0.4 & 3.6 & 34 & 0 & & \\
\hline W.Ry. & 1.3 & 0.9 & 3.4 & 125 & & & Essentially normal liver [19] \\
\hline J.B. & 21.0 & 1.5 & 2.4 & 42 & & 300 & $\begin{array}{l}\text { Occasional fat globule in par- } \\
\text { enchymal cells and minimal } \\
\text { increase of portal fibrous } \\
\text { tissue } \\
{[19]}\end{array}$ \\
\hline W.H. & 11.0 & 1.9 & 1.4 & & 0 & & Essentially normal liver $[59]$ \\
\hline
\end{tabular}

* BSP = bromosulfophthalein; alk. phos. = alkaline phosphatase(Bessey-Lowry); SGO-T = glutamic-oxalacetic transaminase; Ceph. floc. = cephalin flocculation.

$\dagger$ Biopsies were kindly performed by Dr. J. Donald Ostrow of the Thorndike Memorial Laboratory and specially processed ${ }_{2}$ by $_{2}$ Dr. Richard A. MacDonald of the Mallory Institute of Pathology. 


\section{ACKNOWLEDGMENTS}

The authors are grateful to Dr. David Hurwitz for his encouragement and advice throughout these investigations; the members of all of the clinical services of Boston City Hospital; Dr. Richard A. MacDonald for his careful review of the biopsy specimens; Kyra Adler, Rosalie Krasnoff, H. Clement Jurgeleit, Prudence Bunker, and Carolann D'Amico for technical assistance in various phases of the work; and Dr. Solomon A. Berson and Dr. Rosalyn S. Yalow for their generous guidance in our early efforts with insulin immunoassay.

\section{REFERENCES}

1. Brown, T. M., and A. M. Harvey. Spontaneous hypoglycemia in "smoke" drinkers. J. Amer. med. Ass. 1941, 117, 12.

2. Tucker, H. S. G., and W. B. Porter. Hypoglycemia following alcoholic intoxication. Amer. J. med. Sci. 1942, 204, 559.

3. Bottura, C., D. P. Neves, E. Mattar, H. L. de Oliveira, and A. B. U. Cintra. Hipoglicemia e coma hipoglicêmico consequentes à intoxicação aguda por álcool etílico. Rev. Hosp. Clin. Fac. Med. S. Paulo 1949, 4, 133.

4. Neves, D. P., C. V. Faria, and T. Fujioka. Hiperglicemia e hipoglicemia consequentes à intoxicação aguda e crônica pelo álcool etílico. Rev. Hosp. Clin. Fac. Med. S. Paulo 1950, 5, 115.

5. Taylor, J. S. Hypoglycaemia in chronic alcuholism. Brit. med. J. 1955, 1, 648.

6. Hammack, W. J. Solox intoxication. J. Amer. med. Ass. 1957, 165, 24.

7. Peluffo, E., V. Scolpini, J. Grezzi, and N. Tarallo. Coma hipoglucemico e ingestion de bebidas alcoholicas en ninos. Arch. Pediat. Urug. 1958, 29, 94.

8. Hed, R. Clinical studies in chronic alcoholism. II. Carbohydrate metabolism in chronic alcoholism with particular reference to glucose and insulin tolerances. Acta med. scand. 1958, 162, 195.

9. Jeune, M., J. Cotte, et J. L. Nivelon. Coma hypoglycémique au cours d'une intoxication alcoolique aiguë chez un enfant de quatre ans. Pédiatrie 1960, 15,664 .

10. Weill, J., and J.-C. Gorouben. Les hypoglycémies alcooliques. Bull. Soc. med. Hôp. (Paris) 1960, $76,1270$.

11. Cummins, L. H. Hypoglycemia and convulsions in children following alcohol ingestion. J. Pediat. 1961, 58, 23.

12. Neame, P. B., and S. M. Joubert. Postalcoholic hypoglycaemia and toxic hepatitis. Lancet 1961, 2, 893.

13. Freinkel, N., D. L. Singer, C. K. Silbert, and J. B. Anderson. Studies on the pathogenesis and clinical features of "alcoholic hypoglycemia" (abstract). J. clin. Invest. 1962, 41, 1359.
14. Froesch, E. R., and A. E. Renold. Specific enzymatic determination of glucose in blood and urine using glucose oxidase. Diabetes 1956, 5, 1.

15. Sobel, C., O. J. Golub, R. J. Henry, S. L. Jacobs, and G. K. Basu. Study of the Norymberski methods for determination of 17-ketogenic steroids (17hydroxycorticosteroids) in urine. J. clin. Endocr. 1958, 18, 208.

16. Horwitt, B. N. Determination of total 17-OH-corticosteroids. Fed. Proc. 1961, 20, 179.

17. Nelson, N. A photometric adaptation of the Somogyi method for the determination of glucose. J. biol. Chem. 1944, 153, 375.

18. Newman, E. J., and H. W. Newman. A microdiffusion method for alcohol determination. Stanf. med. Bull. 1953, 11, 96.

19. Fiske, C. H., and Y. Subbarow. The colorimetric determination of phosphorus. J. biol. Chem. 1925, 66, 375 .

20. Caraway, W. T. A stable starch substrate for the determination of amylase in serum and other body fluids. Amer. J. clin. Path. 1959, 32, 97.

21. Reitman, S., and S. Frankel. A colorimetric method for the determination of serum glutamic oxalacetic and glutamic pyruvic transaminases. Amer. J. clin. Path. 1957, 28, 56.

22. Huggett, A. St. G., and D. A. Nixon. Use of glucose oxidase, peroxidase, and $o$-dianisidine in determination of blood and urinary glucose. Lancet 1957, 2, 368.

23. Dole, V. P. A relation between non-esterified fatty acids in plasma and the metabolism of glucose. J. clin. Invest. 1956, 35, 150.

24. Trout, D. L., E. H. Estes, Jr., and S. J. Friedberg. Titration of free fatty acids of plasma: a study of current methods and a new modification. J. Lipid Res. 1960, 1, 199.

25. Yalow, R. S., and S. A. Berson. Immunoassay of endogenous plasma insulin in man. J. clin. Invest. 1960, 39, 1157.

26. Berson, S. A., R. S. Yalow, A. Bauman, M. A. Rothschild, and K. Newerly. Insulin- $\mathrm{I}^{131}$ metabolism in human subjects: demonstration of insulin binding globulin in the circulation of insulin treated subjects. J. clin. Invest. 1956, 35, 170.

27. Liddle, G. W., H. L. Estep, J. W. Kendall, Jr., W. C. Williams, Jr., and A. W. Townes. Clinical application of a new test of pituitary reserve. J. clin. Endocr. 1959, 19, 875.

28. Fraser, R., F. Albright, and P. H. Smith. The value of the glucose tolerance test, the insulin tolerance test, and the glucose-insulin tolerance test in the diagnosis of endocrinologic disorders of glucose metabolism. J. clin. Endocr. 1941, 1, 297.

29. Engel, F. L., and J. L. Scott. The insulin-glucose tolerance test. A modified procedure for the detection of hypoglycemia unresponsiveness in pituitary and adrenal insufficiency. $\mathrm{J}$. clin. Invest. 1950, 29, 151. 
30. Williams, R. H. The pancreas in Textbook of Endocrinology, 3rd ed., R. H. Williams, Ed. Philadelphia and London, W. B. Saunders, 1962, p. 621.

31. Goldfien, A., R. Moore, S. Zileli, L. L. Havens, L. Boling, and G. W. Thorn. Plasma epinephrine and norepinephrine levels during insulin-induced hypoglycemia. J. clin. Endocr. 1961, 21, 296.

32. Kinsell, L. W., G. D. Michaels, H. A. Weiss, and H. C. Barton, Jr. Studies in hepatic glycogen storage: I. Adrenalin-induced hyperglycemia as an index of liver function. Amer. J. med. Sci. 1949, $217,554$.

33. Unger, R. H., and L. L. Madison. Comparison of response to intravenously administered sodium tolbutamide in mild diabetic and nondiabetic subjects. J. clin. Invest. 1958, 37, 627.

34. Kaplan, N. M. Tolbutamide tolerance test in carbohydrate metabolism evaluation. Arch. intern. Med. 1961, 107, 212.

35. Fajans, S. S., J. M. Schneider, D. E. Schteingart, and J. W. Conn. The diagnostic value of sodium tolbutamide in hypoglycemic states. J. clin. Endocr. 1961, 21, 371.

36. Cochrane, W. A., W. W. Payne, M. J. Simpkiss, and L. I. Woolf. Familial hypoglycemia precipitated by amino acids. J. clin. Invest. 1956, 35, 411.

37. DiGeorge, A. M., V. H. Auerbach, and C. C. Mabry. Elevated serum insulin associated with leucine-induced hypoglycaemia. Nature (Lond.) 1960, 188, 1036.

38. Grumbach, M. M., and S. L. Kaplan. Amino acid and alpha-keto acid-induced hyperinsulinism in the leucine-sensitive type of infantile and childhood hypoglycemia. J. Pediat. 1960, 57, 346.

39. Wood, F. C., Jr., L. Domenge, P. R. Bally, A. E. Renold, and G. W. Thorn. Studies on the metabolic response to prolonged fasting. Med. Clin. N. Amer. 1960, 44, 1371.

40. Bolinger, R. E., S. R. Shane, and C. H. Kirkpatrick. Secondary rise in plasma free fatty acids following glucose load. J. clin. Endocr. 1962, 22, 873.

41. Lieber, C. S., W. S. George, and S. W. Stein. Effect of ethanol on plasma free fatty acids (FFA) in man (abstract). Clin. Res. 1960, 8, 242.

42. Lieber, C. S., C. M. Leevy, S. W. Stein, W. S. George, G. R. Cherrick, W. H. Abelmann, and C. S. Davidson. Effect of ethanol on plasma free fatty acids in man. J. Lab. clin. Med. 1962, 59, 826.

43. Conn, J. W., and H. C. Seltzer. Spontaneous hypoglycemia. Amer. J. Med. 1955, 19, 460.

44. Williams, R. H. Hypoglycemosis in Diabetes, R. H. Williams, Ed. New York, Paul B. Hoeber, 1960, p. 723.

45. Freinkel, N., and S. J. Bleicher. The physiological basis for the evaluation of the "fasting hypoglycemias." Amer. J. Surg. 1963, 105, 730.
46. Klingman, G. I., McC. Goodall. Urinary epinephrine and levarterenol excretion during acute sublethal alcohol intoxication in dogs. J. Pharmacol. exp. Ther. 1957, 121, 313.

47. Von Wartburg, J. P., W. Berli, and H. Aebi. Der Einfluss langdauernder Äthylalkoholbelastung auf die Katecholaminausscheidung im Harn der Ratte. Helv. med. Acta 1961, 28, 89.

48. Gursey, D., and R. E. Olson. Depression of serotonin and norepinephrine levels in brain stem of rabbit by ethanol. Proc. Soc. exp. Biol. (N. Y.) 1960, 104, 280.

49. Westerfeld, W. W., and M. P. Schulman. Some biochemical aspects of the alcohol problem. Quart. J. Stud. Alcohol 1959, 20, 439.

50. Hökfelt, B. Noradrenaline and adrenaline in mammalian tissues. Distribution under normal and pathological conditions with special reference to the endocrine system. Acta physiol. scand. 1952, 25, suppl. 92.

51. Udenfriend, S., J. R. Cooper, C. T. Clark, and J. E. Baer. Rate of turnover of epinephrine in the adrenal medulla. Science 1953, 117, 663.

52. Van Gool, J., and C. Korn. Hypoglycaemia in rats as a result of spinal cord lesions. Quart. J. exp. Physiol. 1961, 46, 310.

53. Field, J. B., and H. E. Williams. Studies on the mechanism of ethanol-induced hypoglycemia (abstract). J. clin. Invest. 1962, 41, 1357.

54. Fritz, I. B. Factors influencing the rates of longchain fatty acid oxidation and synthesis in mammalian systems. Physiol. Rev. 1961, 41, 52.

55. Renold, A. E., C.-T. Teng, F. B. Nesbett, and A. B. Hastings. Studies on carbohydrate metabolism in rat liver slices. II. The effect of fasting and of hormonal deficiencies. J. biol. Chem. 1953, 204, 533.

56. Schulman, J. L., and S. E. Greben. The effect of glucagon on the blood glucose level and the clinical state in the presence of marked insulin hypoglycemia. J. clin. Invest. 1957, 36, 74.

57. Fajans, S. S., R. F. Knopf, J. C. Floyd, Jr., L. Power, and J. W. Conn. The experimental induction in man of sensitivity to leucine hypoglycemia. J. clin. Invest. 1963, 42, 216.

58. Gley, E., and R. Hazard. Excitation des sécrétions externe et interne du pancréas par le même excitant après surrénalectomie. C. R. Soc. Biol. (Paris) 1928, 99, 195.

59. Zunz, E., and J. La Barre. Sur les causes de l'hyperinsulinémie consécutive à l'injection intraveineuse de solution de sécrétine non hypotensive. C. R. Soc. Biol. (Paris) 1928, 99, 335.

60. Santos, R. N. The effect of duodenal secretin upon the secretion of insulin by the pancreas. Endocrinology 1928, 12, 199.

61. Newman, H. W., and H. G. Mehrtens. Effect of intravenous injection of ethyl alcohol on gastric se- 
cretion in man. Proc. Soc. exp. Biol. (N. Y.) 1932, 30, 145.

62. Antoniades, H. N., K. Gundersen, P. M. Beigelman, H. M. Pyle, and J. A. Bougas. Studies on the state, transport and regulation of insulin in human blood. Diabetes 1962, 11, 261.

63. Samaan, N. A., W. J. Dempster, R. Fraser, N. W. Please, and D. Stillman. Further immunological studies on the form of circulating insulin. J. Endocr. 1962, 24, 263.

64. Yalow, R. S., H. Black, M. Villazon, and S. A. Berson. Comparison of plasma insulin levels following administration of tolbutamide and glucose. Diabetes 1960, 9, 356 .

65. Madison, L. L., B. Combes, R. H. Unger, and N. Kaplan. The relationship between the mechanism of action of the sulfonylureas and the secretion of insulin into the portal circulation. Ann. N. Y. Acad. Sci. 1959, 74, 548.

66. Mortimore, G. E., F. Tietze, and D. Stetten, Jr. Metabolism of insulin- $\mathrm{I}^{131}$. Studies in isolated, perfused rat liver and hind-limb preparations. Diabetes 1959, 8, 307.

67. Forsander, O., N. Räihä, and H. Suomalainen. Alkoholoxydation und Bildung von Acetoacetat in normaler und glykogenarmer intakter Rattenleber. Hoppe-Seylers Z. physiol. Chem. 1958, 312, 243.

68. Smith, M. E., and H. W. Newman. The rate of ethanol metabolism in fed and fasting animals. J. biol. Chem. 1959, 234, 1544.

69. Seligson, D., H. H. Stone, and P. Nemir, Jr. The metabolism of ethanol in man. Surg. Forum 1959, 9, 85.

70. Lieber, C. S., and C. S. Davidson. Some metabolic effects of ethyl alcohol. Amer. J. Med. 1962, 33, 319.

71. Westerfeld, W. W. The intermediary metabolism of alcohol. Amer. J. clin. Nutr. 1961, 9, 426.

72. Lundquist, F., N. Tygstrup, K. Winkler, K. Mellemgaard, and S. Munck-Petersen. Ethanol metabolism and production of free acetate in the human liver. J. clin. Invest. 1962, 41, 955. 